\title{
1 Identifying palaeo-ice-stream tributaries on hard beds: mapping glacial bedforms 2 and erosion zones in NW Scotland
}

\section{Tom Bradwell*}

British Geological Survey, Murchison House, West Mains Road, Edinburgh, EH9 3LA, UK

*Tel.: +44 131 6671000; Fax: +44 6681535; E-mail: tbrad@bgs.ac.uk

\section{Abstract}

Ice streams are fed by tributaries that can extend deep into the heart of ice sheets. These tributaries are born at onset zones - the abrupt transitions from slow sheet flow to fast streaming flow that often occur at significant topographic steps on hard beds (bedrock-dominated beds). For this reason, tributary onset zones leave only a subtle erosional geomorphic signature in the landscape record that is rarely studied. This paper examines, in detail, the geomorphic signature of ice-sheet flow on a hard bed at the head of a palaeo-ice stream. We use field survey techniques to map glacial bedforms within an $\sim 200-\mathrm{km}^{2}$ area of hard crystalline bedrock in a landscape of 'areal scour' around Loch Laxford in NW Scotland. The bedrock bedforms range from plastically moulded ( $p$-forms) and wholly abraded forms, to stoss-lee forms and plucked surfaces all on an outcrop scale (1-100 m). We devise a five-zone classification system to map (in a GIS) the presence, absence, and abundance of glacial erosional forms within 619 (500-m square) grid cells. We go on to use these erosional bedform zones, along with known glaciological relationships to interpret the spatial and altitudinal pattern of palaeo-ice sheet processes and glacier dynamics in this part of NW Scotland. Our interpretation highlights the strong vertical thermal zonation on mountains, and the spatial variations in ice rheology (softness), ice temperature and, by inference, ice velocity in troughs - intimately associated with the onset of ice streaming in tributaries. Consequently, we define the Laxfjord palaeo-ice-stream tributary - a feeder to the Minch palaeo-ice stream in NW Scotland. Finally, we suggest that this new mapping approach could be performed in other deglaciated hard-bed terrain to examine, more widely, the subtle erosional signatures preserved in areas traditionally thought to represent ice sheet 'areal scour'. 
Ice streams and their tributaries are the major conveyors of mass within ice sheets (Bentley, 1987; Bamber et al., 2000), with the transition from slow sheet flow to fast streaming flow occurring at the onset zone (Bindschadler et al., 2000; Whillans et al., 2001). Radar-derived ice velocity maps from Antarctica and Greenland show these tributaries can extend into the heart of ice sheets, with the downstream velocity transition involving an order of magnitude or more increase (from $<10$ to $>$ $400 \mathrm{~m} / \mathrm{a}$ ) over a relatively short distance (approximately tens of kilometres) (Joughin et al., 2002, 2010; Rignot et al., 2011). Joughin et al. (2002) defined two types of onset zone: an upper one where inland flow velocities increase rapidly at the head of ice stream tributaries (typically to $50-150 \mathrm{~m} / \mathrm{a}$ ); and another further downstream where these tributaries converge and accelerate to full ice stream velocities (> $400 \mathrm{~m} / \mathrm{a}$ ). The upper, tributary onsets, are normally associated with abrupt increases in basal-shear stress related to changes in subglacial topography such as flow into troughs; whereas the lower, ice stream onsets, normally occur in low basal shear stress regions where ice emerges from confining subglacial valleys and ice stream tributaries increase rapidly in width (e.g. Paterson, 1994, Bindschadler et al., 2000; Whillans et al., 2001; Joughin et al., 2002, 2010). By definition, tributary onset marks a thermal transition from ice frozen to its bed to warm-based ice lubricated at its bed; whereas ice stream onset may be a complex function of decreased lateral drag and decreased bed resistance (Bindschadler et al., 2000; Whillans et al., 2001; Joughin et al., 2002). Ice sheet flow around high relief topography and into subglacial troughs has long been suggested as a mechanism for perturbing the temperature and stress field of ice sheets, causing fast flow onset and organization into streams of differing erosional capability (Sugden, 1968, 1974, 1977; Mclntyre, 1985). More recently, numerical modelling experiments have emphasized the importance of topographic focusing and strain heating on the flow dynamics of ice sheets (Payne and Dongelmans, 1997; Hindmarsh, 2001; Boulton and Hagdorn, 2006). Flow focusing, or channelling, concentrates strain heating in areas of low elevation, increasing ice temperature and leading to increased ice deformation rates and increased rheological softness (Nye, 1957; Paterson, 1994; Hindmarsh, 2001). 
Much of this ice deformation is concentrated in the basal layers but can involve large components of both vertical and lateral shear (Truffer and Echelmeyer, 2003; Clarke, 2005). Deep mountain passes and narrow topographic cols aligned with ice flow are therefore ideal places to see evidence of ice softening (i.e. higher plasticity) owing to increased basal shear stresses and strain heating, possibly augmented by enhanced creep and increased liquid water content (Clarke et al., 1977; Duval, 1977; Echelmeyer et al., 1994). Unsurprisingly, topographic steps have also been associated with the onset of palaeo-ice streams in formerly glaciated settings (Stokes and Clark, 2001; Kleman and Glasser, 2007; Briner et al., 2006, 2008; Bradwell et al., 2008b; Winsborrow et al., 2010), yet little detailed work has been done to characterise the glacial geomorphology in these settings.

From a palaeo-glaciological perspective, identification and examination of palaeo-onset zones in the landscape record allows glaciological inferences to be made regarding former ice sheet dynamics, thermal regimes, and flow characteristics. Unfortunately for geomorphologists, onset zones typically occur in bedrock-dominated (hard-bed) areas, with only thin or very limited sediment cover; hence their geomorphic signature is largely reflected in the erosion record (Stokes and Clark, 2001; De Angelis and Kleman, 2008; Briner et al., 2008; Winsborrow et al., 2010; Ross et al., 2011). Bedrock (hard-bed) landforms produced by glacial erosion are an important tool for understanding glacial processes but have received relatively little attention compared to their soft-bed counterparts (cf. Piotrowski et al., 2004; Menzies and Brand, 2007; Clark et al., 2009; Stokes et al., 2011). Although subtle differences in bedrock bedform morphology have long been regarded as valuable indicators of former subglacial processes (e.g. MacClintock, 1953; Sugden, 1978; Evans, 1996; Glasser and Bennett, 2004; Roberts and Long, 2005), few have analysed these morphological variations on hard beds over large areas in detail. Recently, however, Trommelen et al. (2012) outlined a new and promising spatio-temporal glacial terrain zone approach, using remote sensing data in combination with fieldwork, to map bedrock and sedimentary bedforms and establish a relative chronology across a large area of complex subglacial terrain $\left(8100 \mathrm{~km}^{2}\right)$ within the core of the former Laurentide 
Landscapes of glacial erosion versus no-glacial erosion have been used effectively by numerous workers examining the thermal regime and (minimum) thickness of former ice masses (e.g., Sugden, 1977; Kleman, 1994; Kleman et al., 1999; Briner et al., 2006; De Angelis and Kleman, 2008; Fabel et al., 2012; Trommelen et al., 2012). However, reconstructions of former ice dynamics (i.e., velocity, ice rheology, flow mechanics, etc.) from erosional landform evidence are far less common (Gordon, 1979; Hall and Glasser, 2003; Roberts and Long, 2005; Bradwell et al., 2008a, Eyles, 2012). The relative paucity of research in this field probably stems from four main reasons: (i) it is still unclear how some glaciological processes are reflected in the erosional landform record; (ii) bedrock properties can mask or influence landform evolution, especially in areas of strong structural control; (iii) glacio-erosional evidence is sometimes difficult to discern in remotely sensed imagery; and (iv) complex glacio-erosional forms can relate to more than one erosional event.

In this paper we examine, in detail, the geomorphic signature of ice-sheet flow on a hard bed with major topographic obstacles - the dissected mountain range of the NW Scottish Highlands. We use a geomorphological approach to classify and map erosional bedrock bedforms, on the outcrop scale (1-100 m) chiefly on a single rock type, across a large study area in NW Scotland. The field area includes ca. $200 \mathrm{~km}^{2}$ of glaciated Precambrian shield rock terrain. This rugged cnoc and lochan topography (Linton, 1963) is often taken to be a classic landscape of 'areal scour' - thought to be the result of widespread and laterally unconfined ice-sheet erosion over several glacial cycles (Sugden and John, 1976; Haynes, 1977; Sugden, 1978; Rea and Evans, 1996; Benn and Evans, 2010). However, this idea has not been rigorously tested. Crucially, our new approach takes outcrop-scale bedforms, which yield point information about the basal processes operating at the local scale, and synthesises this data over a wider area in an attempt to understand ice-sheet processes and patterns on a broader landscape scale (cf. Sugden, 1978; Trommelen et al., 2012). This empirical field-based approach, examining relatively small features $\left(\sim 10^{1} \mathrm{~m}^{2}\right)$ over wide spatial scales $\left(\sim 10^{8} \mathrm{~m}^{2}\right)$, is rarely practised in palaeoglaciology. 


\section{Study area}

\subsection{Physiography, geology, and palaeoglaciology}

The study area is defined by a rectangular box, $13 \mathrm{~km}$ north-south by $22 \mathrm{~km}$ east-west, centred on the head of Loch Laxford in NW Scotland (Figs. 1, 2) and includes part of the ancient dissected mountain range of the NW Highlands [Laxford = laxfjord: from the norse for salmon inlet]. The field area stretches from Badcall Bay in the south to Loch Inchard in the north, and east almost as far as the geographical watershed - a total land area (including inshore water bodies) of ca. $200 \mathrm{~km}^{2}$ (Fig. 2). The influence of bedrock geology and structure on the large-scale landscape of this part of NW Scotland is strong and well established (Peach et al., 1907; Krabbendam and Bradwell, 2010). The landscape can be divided into two physiographic types: (i) the cnoc-and-lochan terrain of the Lewisian gneiss complex, comprising around $80 \%$ of the study area; and (ii) the quartzite-capped mountains (inselbergs), comprising around $20 \%$. The cnoc-and-lochan terrain is a low-lying, extremely rugged, undulating landscape of rock basins (lochans) and rock hills (cnocs) rarely exceeding $200 \mathrm{~m}$ in elevation with relief typically around $100 \mathrm{~m}$ (Fig. 3). The inselberg of Ben Stack (721 $\mathrm{m}$ ) and the broad hills Ben Dreavie $(501 \mathrm{~m})$ and Ben Auskaird $(387 \mathrm{~m})$ are the only notable high points within the Lewisian gneiss terrain. The quartzite-capped mountains are the two (conjoined) massifs of Arkle and Foinaven, the latter reaching $915 \mathrm{~m}$ in elevation. The mountains are ancient upstanding masses of Lewisian gneiss unconformably capped by gently dipping, tectonically thickened strata of Cambrian quartzite. Ben Stack also has a very small residual cap of Cambrian quartzite at summit level (> $700 \mathrm{~m}$ asl). The island of Handa is geologically distinct from the mainland and comprises a generally featureless gently dipping slab of Torridon sandstone, with 100-m high vertical cliffs along its western coast. 
The 'cnoc and lochan' terrain of NW Scotland is an example of a deglaciated, rough, hard ice-sheet bed. The roughness of a glacier's bed can be determined by the number, size, and spacing of bedrock bumps and irregularities - although no standardised definition exists. Topographic profiles, drawn parallel to and perpendicular to former ice flow, show typical bed roughness within the study area (Fig. 3). For simplicity these were calculated using the NEXTMap Britain digital elevation model (DEM) and are expressed as the total length of the surface profile divided by the planar or 'map' distance. Values for both transects are between 1.02 and 1.03 . These bed-roughness profiles underline the rugged, highly undulating nature of the Lewisian gneiss shield rock terrain in NW Scotland (Fig. 3).

The bedrock geology of the study area can be simply classified into two main units. The Lewisian Gneiss Complex, a residual fragment of the Laurentian Shield, comprises felsic to intermediate orthogneiss (coarse-grained, crystalline, meta-igneous rock) with occasional lenses of mafic orthogneiss (typically finer grained), all of Archaean age. The gneisses are characterised by mineral layering (felsic and mafic), typically on a centimetre-scale. The gneisses are cross-cut by dolerite dykes with a strong WNW-ESE trend, part of the Scourie Dyke Swarm (Fig. 2). In the vicinity of Loch Laxford, a marked WNW-ESE trending, 2-3 km wide, ductile shear zone occurs. This shear zone includes a number of thin granite sheets; together with the Scourie dykes these give the appearance of a strong structural 'grain' in this part of NW Scotland. Several sets of large-scale brittle structures occur (faults and joints), which are now associated with zones of locally intense fracturing (Beacom et al., 2001). In addition, NNE-SSW and NNW-SSE trending conjugate fracture sets cut the gneisses on a range of scales (typically from $10^{2}-10^{3} \mathrm{~m}$ ).

The Cambrian Strata comprise generally medium- to coarse-grained, cross-bedded, almost pure quartzite (metamorphosed sandstone). The rock contains $<10 \%$ feldspar grains and is tightly packed with very little matrix. The Cambrian quartzite has been thickened considerably (up to $500 \mathrm{~m}$ ) to form the upper parts of the mountains of Arkle and Foinaven. Within the study area, Neoproterozoic 
rocks of the Torridon Group occur only on the island of Handa where they comprise thickly bedded, coarse-grained sandstones with a clay-hematite matrix (Fig. 2).

The glacigenic superficial deposits in the study area are thin and patchy, forming discontinuous spreads and isolated patches of glacial diamict, morainic debris, and outwash gravel. With the exception of the large body of glaciofluvial (outwash) gravel at the head of Loch Laxford extending 5 $\mathrm{km}$ inland to Loch Stack, the superficial deposits are typically small in area $\left(>0.5 \mathrm{~km}^{2}\right)$ and thin $(<5 \mathrm{~m}$ thick). Recent mapping shows that the glacigenic superficial deposits cover $<15 \%$ of the total land area under study (BGS, 2009). However, considerable Holocene peat accumulations occur particularly in the east, concealing bedrock outcrops in topographic hollows.

In a now-seminal geomorphological study of Scotland, Haynes (1977) classified the cnoc-and-lochan terrain in the study area as a landscape of "areal scouring" representing an area of "very high modification by ice sheets". The high ground to the east was classified as "mountains and plateaux heavily dissected by troughs and corries" representing an area of very high "modification by local alpine glaciations" and "low (or no) modification by ice sheets" (Fig. 4). Recent detailed mapping has shown that the study area lies just outside the area covered by Younger Dryas ice-cap glaciation (Benn and Lukas, 2006; Lukas and Bradwell, 2010) but was covered by the last ice sheet to affect the British Isles, during the Late Pleistocene ( 35-15 ka BP) (Bradwell et al., 2008a). The whole study area lies within the inferred catchment of the Minch palaeo-ice stream that drained the NW sector of the Pleistocene British-Irish Ice Sheet, probably over several glacial cycles (Stoker and Bradwell, 2005; Bradwell et al., 2007). Hence, the glacial erosional features of the cnoc-and-lochan terrain can be assumed to relate to Pleistocene ice sheet glaciation(s). Small independent alpine glaciers probably formed in the northern corries of Arkle and Foinaven at times during the Pleistocene, but these sites were deliberately not examined as part of this work. 
Studies dealing with glacial erosional forms must have a firm understanding of the bedrock forming the focus of the study and its mechanical properties. Although the specific rock mechanics of the two main rock types (Lewisian gneiss and Cambrian quartzite) have not been analysed in detail as part of this work, we draw on research recently carried out in the wider area. Krabbendam and Glasser (2011) examined the hardness and tensile strength of the Cambrian quartzite, Torridon sandstone, and Lewisian gneiss in order to study their relative susceptibility to glacial plucking and abrasion. The results of their field studies, incorporating schmidt hammer rebound and joint spacing measurements, found that Cambrian quartzite in NW Scotland has a typical hardness ( $r$-value) of 60; whilst Lewisian gneiss has a typical hardness of c. 55. Joint spacing in the quartzite was found to be close, $\sim 0.3 \mathrm{~m}$, compared to the gneiss, which has an average of 1-2 $\mathrm{m}$ (within a wide range of $0.5-3$ m) (Krabbendam and Glasser, 2011). A detailed study in the Loch Laxford region showed that joint spacings in Lewisian gneiss could range across two orders of magnitude (0.01-10 m) (Beacom et al., 2001). Krabbendam and Glasser (2011) agreed with previous workers (e.g. Augustinus, 1995; Harbor, 1995; Dühnforth et al., 2010) that the degree to which certain rock types are eroded by glaciomechanical processes is predominantly a function of rock hardness and joint (or fracture) spacing. Under the assumption of stable or constant subglacial conditions, they went on to define rocks based on their dominant erosion mechanism; quartzite fell in the "plucking-dominant" category whilst Torridon sandstone plotted in the "abrasion-dominant" class. Importantly, field data for Lewisian gneiss fell between these two categories, where plucking and abrasion are of "broadly equal dominance" (Krabbendam and Glasser, 2011). It is therefore likely that in 'areally scoured' gneisses such as the cnoc-and-lochan terrain of NW Scotland, the dominant erosion mechanism will be largely determined by glacial conditions (i.e., ice thickness, velocity, bed contact, etc.) but with local variations in rock properties, such as hardness or fracture spacing, also playing a part. 
204

205

206

207

208

209

210

211

212

213

In this study we refer to the following glacial erosional landforms, compiled from authoritative definitions provided elsewhere (e.g., Sugden and John, 1976; Glasser and Bennett, 2004; Benn and Evans, 2010).

Roches moutonnées are partly streamlined, asymmetrical stoss-lee bedrock eminences, typically with a smooth curvilinear stoss slope and a steep or truncated lee slope when viewed in longitudinal cross section. Stoss slopes are formed by abrasion of rock on up-ice (high pressure) faces; lee slopes are formed by plucking, fracturing, or block removal of rock in down-ice (low pressure) cavities. Partly streamlined (stoss-lee) bedrock features have been associated with specific basal conditions in numerous previous palaeoglaciological studies. Typically, roches moutonnées are equated with areas where basal sliding velocities are sufficiently high and ice overburden pressures are sufficiently low to allow cavity formation and hence plucking. It is thought that these conditions are best satisfied beneath relatively thin, fast-flowing ice, where subglacial cavity pressures are likely to fluctuate rapidly in response to basal meltwater flux (Boulton, 1979; Iverson, 1991; Sugden et al., 1992; Evans, 1996; Glasser and Bennett, 2004).

Whalebacks are typically (but not always) symmetrical, rounded, often streamlined, bedrock eminences, with smooth curvilinear stoss slopes and smooth curvilinear 'lee' slopes when viewed in longitudinal cross section. All surfaces are abraded by debris-charged ice flowing over and around (hence remaining in contact with) the entire rock eminence. They are commonly ornamented with $\mathrm{p}$ forms (see below). Plucking does not contribute to the creation of whaleback forms. Wholly abraded bedrock forms, such as whalebacks, have been associated with a range of basal conditions in previous palaeoglaciological studies but typically relate to areas of thicker, softer (warmer) ice under high effective pressures, as deduced by the absence of cavity development and plucking. These conditions are envisaged to occur principally in two settings: (i) beneath thick but relatively slowsliding ice with little basal meltwater (Evans, 1996; Glasser and Bennett, 2004); and (ii) beneath 
thick, relatively fast-sliding ice with stable basal meltwater pressures (Evans, 1996, Benn and Evans, 2010).

P-forms (plastically moulded forms) (Dahl, 1965) are a range of morphologically diverse erosional surface features, on an outcrop scale $(0.1-10 \mathrm{~m})$, including streamlined smooth depressions, scallops, and grooves. Owing to the presence of internal striated surfaces, most workers attribute pforms to erosion by soft, debris-charged basal ice deforming under localised high stresses at the bed (e.g., Boulton, 1979; Rea et al., 2000; Benn and Evans, 2010). Empirical studies have shown how enhanced plastic flow around bedrock obstacles can cause basal ice layers to flow at highly variable angles to the main flow direction and erode p-forms, especially when stresses are concentrated around rock fractures (Rea et al., 2000; Benn and Evans, 2010). Some workers choose to classify these features as s-forms where, they argue, meltwater is the dominant erosional agent (Kor et al., 1991; Glasser and Bennett, 2004). Water-sculpted forms include potholes, sinuous channels and undercut 'half-pipes' with or without internal striated surfaces.

\section{Methods}

\subsection{Field survey}

Field surveys in the study area were undertaken over a period of 7 years (between 2003 and 2010). Data collection was done by transect mapping, with the aim to cover as much of the ground as possible using a network of $~ 1-2 \mathrm{~km}$ spaced field-survey lines. Field survey involved walking a course examining every substantial bedrock outcrop encountered for evidence of glacial erosion. Most transect routes were chosen to optimise bedrock exposure. Bedrock outcrops were mapped as one of the following three feature classes: wholly abraded forms (smooth, glacially abraded on all surfaces, plucked faces absent); stoss-lee forms (glacially abraded stoss faces and plucked lee faces); 
252 (and/or s-forms) and orientation of glacial striae were also recorded where encountered. Although this landform classification is somewhat subjective, it is based on the best overall representation of the glacially modified bedrock form and builds on classifications used successfully by others mapping hard-bed glaciated terrain (e.g., Sugden, 1977; Evans, 1996; Sugden and Denton, 2004; Roberts and Long, 2005).

In addition to this information, other pertinent geological observations regarding the bedrock itself (e.g. unusually granitic, mafic, coarse-grained, or brecciated; the degree of surface weathering; etc.) were also recorded. On the highest ground, where no evidence of glacial erosion was observed, a single (null) feature class was used for mapping purposes. These areas were defined by mapping the extent of hilltop regolith or blockfield (where bedrock exposures were absent) along with the presence of any mature periglacial or pre-glacial landforms (e.g. sorted stone nets, tors, relict fluvial features, saprolite, etc.) all thought to represent areas of minimal or no glacial erosion (e.g. Stroeven et al., 2002; Kleman and Glasser, 2007; Fabel et al., 2012)

Owing to the undulating and extremely rugged nature of the terrain, walkover transects involved 'sweeps' typically around $100 \mathrm{~m}$ wide, taking in as many bedrock outcrops as possible. The exact course was plotted using hand-held GPS. All field observations, prior to 2010, were noted using GPS waypoints, a notebook and large-scale $(1: 25,000)$ OS topographic maps; in 2010 observations were made using a field-adapted ruggedised tablet PC running a customised version of ArcGIS. Unfortunately, owing to time constraints and the remote, rugged, nature of the terrain it was not possible to visit all the ground within the study area.

\subsection{Remote sensing data}

The NEXTMap Britain digital elevation model (DEM) is the highest resolution elevation model currently available of the study area in NW Scotland. This airborne radar data set has a horizontal 
resolution of $5 \mathrm{~m}$ and a vertical resolution of ca. $1 \mathrm{~m}$. When this DEM is processed and illuminated

277 (hill-shaded), breaks of slope are clearly visible; vertical exaggeration can also be used to highlight subtle features. This approach has been successfully used to map large- and medium-scale glacial bedforms in the UK by numerous workers (e.g. Bradwell et al., 2007; Hughes et al., 2010; Patton et al., 2012). Mapping experiments in ArcGIS using processed and raw NEXTMap Britain data show that the existing gridded elevation model is too coarse to capture the surface detail required to map small-scale bedrock forms $(<10 \mathrm{~m})$ (Fig. 4). The addition of colour aerial photographs improves mapping resolution visually but cannot improve three-dimensional spatial representation of the bedrock topography without full photogrammetric georeferencing. As this option was not available, the currently available remotely sensed data was unsuitable for the high-resolution geomorphological mapping required in this study. However, an outline of the broad physiographic terrain zones, derived from the NEXTMap DEM (modified from Krabbendam and Bradwell, 2010), is presented for the study area (Fig. 4).

\subsection{Spatial data analysis and zonal map generation}

The field area was gridded using a $500 \times 500 \mathrm{~m}$ cell size, conforming to the British National Grid [OS]. Thirty-six survey transects were undertaken in total, which included data in 619 out of a possible 988 cells (i.e. $63 \%$ of land within $22 \times 13 \mathrm{~km}$ rectangular study area). An overview map was made in ArcGIS showing the results of the geomorphological mapping: the occurrence of wholly abraded forms, stoss-lee forms, p-forms, etc., in every cell visited across the whole study area. Each $500 \times 500$ m cell was then given a value $(0,1,2,3$, or 4$)$ using a five-zone classification scheme based on the dominant feature class (i.e. bedrock bedform) and the presence or absence of $p$-forms. This scheme is outlined in Fig. 5, with some field examples shown in Fig. 6. The zonal classification system has been designed with enough flexibility to accommodate mixed categories without distorting the raw data (i.e. zone 3 = stoss-lee forms and wholly abraded forms both common) (Figs. 5, 6). Where no 
bedrock was encountered in a cell, because of superficial deposit coverage, an 's' was entered.

When no data (or insufficient data points) were recorded in a cell, no value was entered (nv) (Fig. 7).

The results of this exercise are shown as a grid-map in which each attributed cell was colour coded to visually highlight any spatial trends (Fig. 8).

The final grid-map of spatial data was zoned on a domain scale by generating smooth lines around areas, or bedform zones, with the same cell value (Fig. 8). Most zone boundaries could be easily defined based on the sharp transitions between same-value groups of cells (e.g. in the Loch Stack trough). However, in some places, a degree of user interpretation was required to allow a smooth line to be depicted at the domain scale. For example, around the mountains of Ben Stack and Arkle where zone boundaries merged or could not be resolved owing to the 500-m cell size, smooth lines were interpolated across cells. In areas where zone boundaries became diffuse, owing to lack of data, projected lines were used (shown dashed). Finally, a distinction was made between the 'pure' zone 4 landscape and the checkerboard mixed zone 3-zone 4 terrain to the NW (Fig. 8).

\subsection{Sampling and uncertainties}

Our zonal-classification grid-mapping technique produces a single value for each cell surveyed (or partially surveyed), allowing a more complete map (63\% of possible cells) to be made from an incomplete ground survey (20-30\% ground cover). This was considered the optimum, although not the perfect, solution to the problem of mapping large areas of bedrock terrain on foot. The main benefit of this methodology is that it allows observations to be scaled up from the outcrop $\left(<10^{1} \mathrm{~m}^{2}\right)$ to the regional scale $\left(>10^{8} \mathrm{~m}^{2}\right)$ without compromising the integrity of the data or leaving too many large data gaps. The method has potential drawbacks, however; the main ones are listed below.

- Representativeness of the survey lines. Walkover survey of extremely rugged terrain with few vantage points will, naturally, only include a proportion of the ground within any $500 \mathrm{x}$ $500 \mathrm{~m}$ cell and this could introduce a bias. For example, in a single cell with pronounced 
relief, data from low elevation sites may differ from those at high elevation, yet the low elevation sites may be surveyed preferentially because of ease of access. Clearly, the value ascribed to the grid cell will ultimately depend on which part of the ground has been surveyed (or not). To test this hypothesis, and the general reproducibility of the mapping methodology, we performed a repeat survey experiment in a typical area of $1 \mathrm{~km}^{2}$ with undulating relief (Fig. 9). A large proportion ( $>50 \%$ ) of the total possible ground in each cell was mapped; firstly by surveying predominantly high elevation sites, and secondly at generally lower elevations. The results showed that although differences may occur between high elevation and low elevation settings (Fig. 9), and thus different results could be obtained ( 1 cell out of 4 , in this instance), the classification scheme is sufficiently flexible

- Optimum cell size for the gridding system. We chose a cell size that allowed the best trade and the nature of the ground is sufficiently varied to average out any survey bias over the regional scale $\left(>5 \mathrm{~km}^{2}\right)$. off between the number of survey lines needed and the 'blockiness' of the final data set. Initial experiments found that $100-\mathrm{m}$ cells were too numerous to populate over such a large area, and 1000-m cells were too coarse to express the spatial subtleties of the zoned data. We therefore chose $500-\mathrm{m}$ cells as the best way to convey the empirical data at the appropriate final map scale, although it is recognised that smaller cells $(200 \mathrm{~m})$ could be used in smaller field areas.

- Attribution of cells based on too few data. Owing to the nature of the field survey, not all cell values are based on the same number of data points (field observations). No weighting scheme has been adopted in our spatial analysis methodology - with raw field observations translated directly into cell values. The fewest data points (i.e. outcrops visited) in any cell is 4; fewer than 4 was considered as "no data" for the gridding exercise. The greatest number of data points in any cell is 34; with most cells having between 8 and 20. A revised methodology could seek to apply weighting statistics or a ranking scheme to cells with fewer 

observations per cell is sometimes simply dependent on the number of viable bedrock exposures.

\section{Results}

\subsection{Orientation of glacial striae}

The orientation of glacial striae provides primary evidence of former ice-flow directions on bedrock terrain. However, within the study area striae are not well preserved on Lewisian gneiss owing to surface weathering (Fig. 10). Typically, postglacial surface loss on gneiss outcrops is in the region of $5-20 \mathrm{~mm}$, as seen from the protrusion of quartz veins, although this can exceed $30 \mathrm{~mm}$ in mafic intrusions. Well-preserved striae were found in certain protected locations by removing a thin cover of glacial debris or peat (Fig. 10). Glacial striae on Cambrian quartzite outcrops appear unaffected by surface weathering. The overall trend of striae is shown as a rose diagram with orientations grouped in $15^{\circ}$ bins and measurement numbers expressed as a percentage (Fig. 8). Measurements from earlier geological mapping (Geological Survey of Scotland, 1892; BGS, 1998) are also included in this data set. The modal class is $285-300$, indicating former ice-sheet flow from onshore to offshore in a WNW direction, as determined by previous work (Gordon and Sutherland, 1993; Lawson, 1995; Stoker and Bradwell, 2005). Local variations around this general trend were noted especially on the eastern flanks of Arkle and Foinaven (340/160) and in the deep col between the two mountains (240/060) (Fig. 10). 
375

376

377

378

Our new mapping shows the presence or absence of various glacial features (primarily stoss-lee vs. wholly abraded bedforms) on crystalline shield rocks around Loch Laxford and on the surrounding mountains (Fig. 8). The erosional bedform zones defined in the grid-mapping exercise are clearly reflected in the landscape on a regional scale. When draped on the topography (NEXTMap DEM), several key spatial features appear (Fig. 11). The strong correlation between zones 0-1 and elevated topography (>500 $\mathrm{m}$ asl) is not surprising as this geomorphological evidence, relating to little or no glacial erosion, typically only occurs at high elevation (e.g. Sugden and Watts, 1977; McCarroll et al., 1995; Stroeven et al., 2002; Kleman and Glasser, 2007). However, the tendency for zone 1 to persist on lower ground (200-400 $\mathrm{m}$ asl) to the NW of Ben Stack is an unexpected result. Other interesting results include the strong zone partitioning around the isolated mountain of Ben Stack, with zones 3 and 4 terrain along the axis of Strath Stack and zone 4 in the Loch Stack trough $(<300 \mathrm{~m}$ asl) separated from the summit zones $0-1$ by a narrow band of zone 2 terrain at higher elevations. This zone partitioning is mirrored around Arkle, but the pattern is less clear owing to incomplete survey, scree cover, and a change in rock type (gneiss to quartzite) on the eastern slopes. The col between Arkle and Foinaven is a small 'hotspot' of zone 4 terrain at relatively high elevation ( $400 \mathrm{~m}$ asl), surrounded by a large area of zone 1 and zone 2 terrain all on Cambrian quartzite (Fig. 11). At lower elevations $(<300 \mathrm{~m})$, within the Lewisian gneiss complex, zone 2 predominates across most of the ground SW of a line from Ben Stack to Tarbet; zone 3 and 4 predominate to the NE of this line. Exceptions are around Gleann Scourie where a poorly defined patch of zone 3 terrain occurs and on the flanks of Foinaven where a narrow band of zone 2 terrain exists. The broad flat-bottomed Loch Stack trough is characterised by zone 4 terrain stretching far inland, east of gridline 30 . To the NW, beyond a line approximately following the main road (A894), zone 4 terrain becomes less distinct essentially comprising a mixed zone, or irregular checkerboard, of zones 3 and 4 terrain (Fig. 11). Bordering the broad swath of zone 4 terrain, are narrow but clearly defined bands of zone 3 terrain to the NW and SE. Handa, an island of Torridon sandstone, is classified as zone 2 terrain, although 

and peat.

402

\subsection{Comparison with bedrock geology}

When overlain on the bedrock geology (BGS, 2011), an apparent visual correlation is observed between zone 4 terrain and the concentration of thick granite sheets associated with the Laxford Shear Zone (Fig. 11). However, on closer inspection this match is not a strong one, with the granite sheets extending well into zone 3 to the NW of Ben Stack and on the SW flanks of Arkle. Furthermore, well-developed zone 4 terrain occurs on Druim na h-aimnhe, around Ardmore Point and on the islands in Loch Laxford where no substantial granite sheets have been mapped within the Lewisian gneiss complex. This poor overall match between bedrock lithology and erosional bedform zone refutes a general causal link between rock type and bedform distribution. Elsewhere patches of zone 4 terrain in Strath Stack and in the col between Arkle and Foinaven on Cambrian quartzite make a primary geological control on bedform type look highly unlikely (Fig. 11). Any apparent link between bedrock lithology and bedform type in the study area may be coincidence, or may simply reflect the occurrence of granite sheets within a weak, large-scale structural feature (Laxford Shear Zone) which is also now a topographic depression. However, we do acknowledge the important roles

417 played by bedrock hardness and fracture spacing on erosional surface form in certain rocktypes (e.g., Gordon, 1981; Dühnforth et al., 2010; Krabbendam and Glasser, 2011).

\section{Discussion}


422 Our empirically derived map of glacio-erosional bedform zones (Fig. 8) has implications for 423 reconstructing longitudinal, lateral, and vertical variations in palaeo-ice sheet dynamics. In the 424 following section we explore these in more detail, zone by zone, using the occurrence, type, and spatial distribution of bedforms to make inferences about the palaeoglaciology of NW Scotland (see Table 1).

Inland ice sheet flow on hard beds is normally slow because ice is frozen to its bed, or overburden pressures are high, and ice-bed coupling and hence basal drag are high (Paterson, 1994; Bamber et al., 2000; Joughin et al., 2002; Clarke, 2005). However, high shear stresses acting at the bed when ice encounters large topographic obstacles increase the ice temperature through strain heating, combined with topographic flow focusing, to increase ice rheological softness (decreased viscosity) and in turn increase ice flow rate (Nye, 1957; Hindmarsh, 2001; Clarke, 2005). Observational and theoretical studies have shown that these glaciodynamic conditions are associated with a marked velocity transition on hard beds - the onset from slow sheet flow to fast tributary flow (Payne and Dongelmans, 1997; Tulaczyk et al., 2000; Joughin et al., 2002; Schoof, 2005, 2010). We envisage these conditions to have occurred within the study area in zone 4 terrain where the ice sheet was focused between the mountains and into a subglacial trough. These glaciological conditions would have resulted in high bedrock abrasion rates and increased flow - by Weertman-sliding, enhanced ice deformation and ice softening - but little or no basal cavity formation (Weertman, 1957; Lliboutry, 1968; Schoof, 2005). This is entirely consistent with the mapped predominance of wholly abraded forms (whalebacks) and p-forms, and little or no evidence of plucked forms within zone 4. We thereby propose that the mapped extent of zone 4 defines the onset of a palaeo-ice-stream tributary between the mountains of Ben Stack and Arkle and in the Loch Stack trough (Fig. 12).

Further downstream, zone 4 becomes more spatially diffuse and gives way to a checkerboard of zone 3 and zone 4 cells in approximately equal amount. We suggest that this mixed zone (zone 3-4), with an increase in plucked surfaces relative to 'pure' zone 4, corresponds to increased subglacial 
cavity formation, decreased ice-bed coupling, and by inference an increase in basal sliding. We propose that a gradual downstream decrease in ice-sheet thickness, and hence a reduction in iceoverburden pressure, would lead to a relative fall in the basal water pressure threshold required to decouple the ice from its bed. Where basal water pressures exceed the separation pressure, initially in favourable lee-side settings, basal cavity formation leads to an increase in plucking. These lower effective pressures also decrease ice deformation rates near the bed, further enhancing cavity formation (Schoof, 2005, 2010). We therefore envisage fast sliding driven by basal cavity formation and lowered basal drag in this mixed zone (zone 3-4). These glaciological conditions would result in high bedrock abrasion rates and high plucking rates, favouring roches moutonnées production over whaleback forms, entirely consistent with the gradual transition from zone 4 to zone $3-4$. We propose that the mapped distribution of this mixed zone (3-4) represents the geomorphological signature of a transition from Weertman-sliding to cavity-driven basal sliding on a hard bed. Theoretical studies have shown these conditions are characteristic of the longitudinal transition to streaming flow velocities (Tulacyzk et al., 2000; Truffer and Echelmeyer, 2003; Schoof, 2005). Following on from zone 4, we thereby use zone 3-4 to define the downstream sliding transition from sheet flow to streaming flow within a palaeo-ice-stream tributary.

Collectively, we suggest that this whole erosional bedform assemblage (zone 4 and zone 3-4) represents the geomorphological signature of ice stream onset - initially associated with increased driving stress, decreased ice viscosity and a high degree of ice-bed coupling (zone 4), transitioning downstream to increased basal cavity formation, decreased driving stress, increased basal water pressures and a lower degree of ice-bed coupling (zone 3-4). We associate the palaeo-onset zone with a thermal transition from a cold-based to a warm-based ice sheet flowing over a hard bed (Fig. 12). This is in agreement with certain findings of previous studies on similar bedrock bedforms elsewhere (Evans, 1996; Hall and Glasser, 2003; Glasser and Bennett, 2004; Ross et al., 2011). 
471 Currently, zone 3-4 has no defined downstream margin, but we predict that tributary ice streaming 472 persisted only a relatively short distance offshore in Loch Laxford $(<20 \mathrm{~km})$ before coalescing with 473 the trunk of the Minch ice stream and accelerating to 'full' streaming flow velocities $\left(>300 \mathrm{~m} \mathrm{a}^{-1}\right)$. 474 The transitional boundary between zones 4 and 3-4, defined in this study, would be entirely consistent with the downstream change in basal water pressures necessary to facilitating rapid sliding on a hard impermeable bed. It is, however, probably no coincidence that this transition also broadly occurs at the present-day coastline (Loch Laxford) close to the inshore limit of deformable marine sediments.

Zone 3 is characterised by well-developed roches moutonnées and whalebacks in approximately equal proportions augmented with $p$-forms. This zone tends to occur on the flanks of mountains and in areas of relief change but generally not on the lowest elevation ground. Collectively, this bedform assemblage suggests a mobile, warm-based ice sheet with a moderate degree of ice-bed coupling and subglacial cavity formation. Unlike zone 4, these conditions could equate to a range of glaciological settings, but given zone 3's topographic distribution within the study area and its spatial relationship to zone 4, we propose the following optimum glaciological interpretation: relatively high ice-overburden pressures (but lower than zone 4), relatively high basal pressure waters in places (fluctuating around the separation pressure), and thus lower effective pressures (relative to zone 4). Lower effective pressures would decrease ice-bed contact and decrease rates of ice deformation. Furthermore, the topographic setting of zone 3 would generally not be conducive to such high rates of strain heating and ice softening as seen in the Loch Stack trough (zone 4). We therefore envisage widespread basal cavity formation, reduced basal drag, and relatively fast ice flow velocities by cavity-driven basal sliding in zone 3 . These conditions would result in high bedrock abrasion rates and high plucking rates, favouring roches moutonnées production over whaleback forms, with the relative abundance of wholly abraded forms between that of zones 2 and 4 probably representing a transitional setting between suppressed and increased rheological ice softness. We propose that the 
497 form of englacial shear (or strain) margin - separating ice stream tributary flow from the surrounding slower flowing ice (Fig. 12). The velocity gradient and high tensile stresses across these zones would probably have resulted in a highly crevassed ice surface. Under certain stress conditions large water-filled crevasses can penetrate to the bed of thick glaciers (Benn et al., 2007). Interestingly, the notable presence of water-sculpted s-forms in isolated localites (Fig. 6) along the margins of zone 3 may be attributed to this phenomenon.

Zone 2 is dominated by roches moutonnées, with whalebacks and p-forms rare or absent, and occurs at a wide range of elevations. Higher up, it merges with zone 1 terrain; lower down, it forms broad swathes and irregular patches typically adjacent to zone 3 terrain. It appears to make up the majority of the "areally scoured" Lewisian gneiss terrain in the study area, however is notably absent around Loch Laxford and in the Loch Stack trough. Its glaciological significance is more difficult to assess than the other zones. However, an abundance of plucked faces indicate that ice flow has occurred (at least locally) by cavity-driven basal sliding, whilst the co-existence of abraded stoss slopes and rare p-forms also point to a high degree (at least locally) of ice-bed coupling. As in zone 3, there is no unique glaciological setting that satisfies the conditions required to generate this

512 landscape; but given its topographic distribution within the study area and the spatial relationship to other zones, we propose that zone 2 terrain is best explained by moderate ice-overburden pressures

514 (lower than zone 3) generally in higher elevation areas, relatively high basal water pressures 515 (fluctuating around the separation pressure), and thus relatively low effective pressures. Generally, lower effective pressures suppress ice creep rates at the bed; hence, we suggest, away from the deep valleys there would have been limited topographic flow focusing with little or no increased ice softening. We propose that rheologically harder, sliding-dominant ice sheet flow in an unconfined setting is the most likely genetic origin for the erosional zone 2 terrain (Fig. 12). Interestingly, a small patch $\left(\sim 4 \mathrm{~km}^{2}\right)$ of zone 3 terrain occurs in the topographic depression of Gleann Scourie where

521 localised flow focusing and ice softening may have occurred. However, the fact that zone 2 occurs across a wide range of elevation settings ( $10-500 \mathrm{~m}$ asl) could also point to a polygenetic origin. 
Therefore, we stress that the overprinting or modification of this zone by one or more glaciological regime cannot be discounted.

Zone 1 is found predominantly on the flanks of mountains and displays only weak erosional bedforms such as subtle plucked faces and lacks $p$-forms. Zone 0 shows no evidence of glacial erosion and occurs exclusively in the highest elevation areas. Both these zones are bounded, sometimes abruptly, downslope by areas of zones 2,3 , and 4 terrain, where well-developed erosional forms predominate. We relate zone 0 to subglacial frozen-bed patches, where little or no glacial erosion has taken place over whole glacial cycles (Fig. 12). In total we map three such areas and suggest that they represent isolated, immobile, palaeo-frozen bed patches (zone 0) surrounded by thicker, faster sliding, warm-based ice (zones 2, 3). We propose that the frozen-to-thawed bed transition is defined by zone 1 , where only subtle subglacial erosion has occurred probably in the absence of basal metwater. In the study area, we propose that zone 1 is best explained by slowflowing, rheologically hard ice, with low ice-overburden pressures (lower than zone 2) and with limited capacity to erode its substrate. The curious continuation of zone 1 to the NW of Ben Stack on relatively low ground (200-400 m) probably represents a frozen-bed 'shadow' or 'sticky spot' where 538 ice sheet flow and subglacial erosion were restricted in a protected, low shear stress, lee-side setting 539 (Fig. 12).

540 Our systematic bedform mapping shows that the summit ridges and plateaux of Ben Stack, Arkle and 541 Foinaven, characterised by little or no erosional evidence (zone 0), were probably frozen-bed 542 patches hosting cold-based ice akin to similar high-elevation settings elsewhere (Kleman et al., 1999; 543 Fabel et al., 2002, Hall and Glasser, 2003). Some workers have used the absence of glacial evidence 544 at high elevation and 'trimlines' to determine the vertical limits of the last ice sheet in NW Scotland 545 (e.g. Ballantyne et al., 1998). However, this approach has since been invalidated largely by 546 cosmogenic-nuclide analyses from above trimlines, and ice-sheet thermal boundaries are now routinely used to explain these phenomena (e.g. Stroeven et al., 2002; Briner et al., 2006; Phillips et 

of mountain ranges at the periphery of large ice masses where frozen-bed patches on mountain summits $\left(0.1-5 \mathrm{~km}^{2}\right)$ are thought to be stable features persisting throughout multiple glacial cycles (Kleman et al., 1999; Kleman and Glasser, 2007). Ongoing work in NW Scotland is seeking to determine the exposure age and erosion history of these high elevation areas using cosmogenicnuclide analyses of bedrock and glacially transported boulders.

When compared with the temperature structure of a present-day hard-bedded ice stream (Truffer and Echelmeyer, 2003), the vertical glacio-erosional zones derived in this study match well with the expected englacial thermal zonation (Fig. 12). The thermal structure of the 'Laxfjord palaeo-icestream tributary' was probably similar to that of Jakobshavn Isbrae and other similar fast-flowing outlets of the Greenland Ice Sheet, but on a smaller scale. The layer of warmer, rheologically softer, temperate ice at the bed - maintained by high ice-overburden pressures and strain heating coincides with the zones of whalebacks and predominantly abraded forms (zones 4 and 3). By contrast, the coldest rheologically hard ice occurs at approximately half the maximum vertical ice thickness - coincident with the mapped upper limit of glacial erosion (zone 1) on the mountains of Ben Stack and Arkle, assuming an ice sheet thickness of ca. 1000-1250 m (Boulton and Hagdorn, 2006; Hubbard et al., 2009). Above this elevation, stable frozen-bed patches would have existed (zone 0) (Fig. 12), as suggested elsewhere (e.g. Kleman, 1994; Briner et al., 2006; Kleman and Glasser, 2007). We infer that preferential preservation of these frozen-bed patches is most likely on narrow ice-flow aligned summits or in lee-side settings, where basal shear stresses would be lowest.

\subsection{Summary of palaeo-ice sheet dynamics in NW Scotland}

In summary, our zonal bedform mapping suggests that high relief topography in NW Scotland perturbed the ice sheet into flow-parallel corridors, or ice stream tributaries, with distinct basal 
572 thermal structures and velocity profiles. This ice sheet structuring - longitudinally, laterally, and

573 vertically - fundamentally determined the erosional capability of the ice sheet and hence its 574 geomorphic effect on the landscape, as proposed by others working in glaciated terrain elsewhere 575 (e.g. Sugden, 1974; Glasser, 1995; Patterson, 1998; Kleman and Glasser, 2007).

576 Our results suggest that enhanced vertical thermal zonation was associated with this topographically 577 controlled ice-sheet flow regime. This phenomena was probably exemplified where ice flow was 578 focused between and the large isolated mountains of Ben Stack and Arkle - with increased shear 579 stresses, increased ice temperature, and hence increased rheological ice softness suppressing icebed separation at low elevation (zone 4); and thinner, cold-based, ice frozen to its bed at high elevation (zone 0). A velocity increase downstream (to the NW) was probably governed by a transition from Weertman-type sliding to cavity-driven basal sliding over a relatively short horizontal distance $(<10 \mathrm{~km})$, as seen in the longitudinal transition from zone 4 to zone $3-4$. The glaciodynamic conditions reconstructed here are all consistent with those found at the onset of contemporary ice stream tributaries (e.g. Tulacyzk et al., 2000; Truffer and Echelmeyer, 2003; Schoof, 2005; Rignot et al., 2011). Subtle spatial differences in bedrock bedform assemblages mapped in the Loch Laxford

587 area have allowed this former ice stream tributary to be defined longitudinally, from its onset (zone 588 4) through transitional tributary flow (zone 3-4), and also laterally where an inferred velocity contrast is marked by flow-parallel (shear or strain) margins (zone 3) (Fig. 12). We relate this geomorphological 'landscape' signature to a palaeo-glaciological feature which we call the Laxfjord ice-stream tributary - a feeder to the Minch palaeo-ice stream.

\subsection{Wider implications for mapping ice-sheet erosion zones}

Our field survey and resulting bedrock bedform-zone map allows inferences to be made about the 
control, be used to assess the dominant palaeo-glaciological processes operating on hard beds (e.g. strong vs. weak ice-bed contact; warm vs. cold ice; Weertman sliding vs. cavity-driven sliding, etc.). Because basal topography and ice thickness strongly influence the basal temperature of polythermal ice sheets and because ice temperature and basal meltwater influence ice flow rates (e.g., Nye, 1957; Paterson, 1994; Clarke, 2005), other qualitative thermodynamic inferences could also be made from the results of this mapping (e.g., relating to ice velocity, ice rheology, effective pressures, etc.). We suggest that this new approach could be transferred to other areas of glaciated bedrock terrain worldwide, in particular the geologically similar Precambrian shield rock provinces of Scandinavia, Greenland, and North America where broad morphological similarities are noted. As in Scotland, these landscapes have been attributed to widespread ice-sheet erosion by 'areal scour' (Linton, 1963; Haynes, 1977; Benn and Evans, 2010) - a concept that could now be refined using the bedform-mapping erosion-zone scheme outlined here. Our new zone-mapping approach opens the possibility of exploring the subtle spatial variations in erosional signature on a landscape scale in order to further our understanding of ice-sheet flow dynamics on hard beds.

We note that making palaeo-glaciological inferences based on the extant landform record is not easy and can be open to interpretation. Glacio-erosional landforms (in bedrock) are particularly challenging to study as their form is, by definition, the cumulative product of erosion possibly over long time periods. We accept that their formation may be time transgressive, may record multiple events, or may reflect an element of pre-glacial inheritance. Furthermore, bedrock structure and lithology can exert a strong influence on landform genesis in certain circumstances. But identifying the degree and pattern of glacial modification in any landscape is the key starting point to understanding its glacial history. We hope that this work has shown that on certain bedrock landscapes, where rocktype is largely uniform or lithological variations are controlled - such as on Precambrian shield rocks - landform assemblages can be used to derive zones of different glacial 
sheet dynamics. We hope that our field-based mapping approach and zone-classification scheme does this in a relatively simple but repeatable way.

624

\section{Conclusions}

626 We have mapped, from field investigations, the glacial erosional forms in a large area (ca. $200 \mathrm{~km}^{2}$ ) 627 of crystalline shield rock terrain in NW Scotland. We have used a new classification scheme, with a 628 500-m cell size, to produce a map of glacio-erosional bedform zones. These zones highlight the cumulative product, spatial distribution, and style of subglacial erosion on a hard-rock former icesheet bed with major topographic obstacles.

Using this field data we have made palaeo-glaciological inferences relating to the degree of ice-bed contact, ice rheology (softness), ice temperature and, by proxy, ice velocity. Consequently, we have proposed the former existence of an ice-stream tributary on a hard bed in NW Scotland. We have tentatively defined its onset zone, transitional flow zone (Weertman-sliding to cavity-driven basal sliding) and lateral margins. We have named this feature the Laxfjord palaeo-ice-stream tributary an important feeder to the Minch palaeo-ice stream. This fast-flowing ice-stream tributary, and others in the wider area, probably governed the strong, vertical, ice-sheet thermal zonation seen on mountains across NW Scotland.

We suggest that the use of a zonal-classification scheme for mapping erosional bedforms on crystalline bedrock could be applied elsewhere, with important implications for the reconstruction of ice rheologies, basal thermal regimes, and fast flow zones in other deglaciated shield rock provinces (e.g., Greenland, Fennoscandia, Canada). Furthermore, we suggest that glacially roughened shield rock or cnoc-and-lochan terrain should not be seen as simply a landscape of 
and the surrounding mountains can actually preserve the subtle signatures of former ice-sheet flow dynamics and thermal regime.

647

\section{ACKNOWLEDGEMENTS}

This work was funded by the British Geological Survey (NERC), Geology and Landscapes UK Programme. Maarten Krabbendam, Neil Glasser, Nick Hulton, and Andrew Finlayson are thanked for comments on an earlier version of this manuscript. The five journal referees and the Editor (R.A. Marston) are all thanked for their comments, in particular lan Evans and Martin Ross for their insightful suggestions that helped to clarify and improve this work. Published with the permission of the Executive Director, BGS (NERC).

\section{REFERENCES}

Augustinus, P., 1995. Glacial valley cross-profile development: the influence of in situ rock stress and rock mass strength, with examples from the Southern Alps, New Zealand. Geomorphology 14, 87-97.

659

660

Ballantyne, C.K., McCarroll, D., Nesje, A., Dahl, S.O., Stone, J.O., 1998. The last ice sheet in NW

661 Scotland: reconstruction and implications. Quaternary Science Reviews 17, 1149-1184.

662

Bamber, J.L., Vaughan, D.G., Joughin, I., 2000. Widespread complex flow in the interior of the Antarctic Ice Sheet. Science 287, 1248-1250.

665

Beacom, L.E., Holdsworth, R.E., McCaffrey, K.J.W., Anderson, T.B., 2001. A quantitative study of the influence of pre-existing compositional and fabric heterogeneities upon fracture-zone development during basement reactivation. In: Holdsworth, R.E., Strachan, R.A., Macgloughlin, J.F., Knipe, R.J. 
(Eds.), The Nature and Significance of Fault Zone Weakening. Geological Society Special Publication

670 186, London, pp. 195-211.

671

672

Benn, D.I., Evans, D.J.A., 2010., Glaciers and Glaciation. Second Edition. Arnold, London.

673

674

Benn, D.I., Lukas, S. 2006.,Younger Dryas glacial landsystems in north west Scotland: an assessment

675

of modern analogues and palaeoclimatic implications. Quaternary Science Reviews 25, 2390-2408.

676

677

Benn, D.I., Warren, C., Mottram, R., 2007. Calving processes and the dynamics of calving glaciers.

Earth-Science Reviews 82, 143-179.

679

680

Bentley, C.R., 1987. Antarctic ice streams: a review. Journal of Geophysical Research 92(B9), 8843-

681 8858.

682

683

Bindschadler, R., Chen, X., Vornberger, P., 2000. The onset area of Ice Stream D, West Antarctica.

Journal of Glaciology 46, 95-101.

685

686

Boulton, G.S., 1979. Processes of glacier erosion on different substrata. Journal of Glaciology 23, 15-

687

38.

688

689

Boulton, G.S., Hagdorn, M., 2006. Glaciology of the British Ice Sheet during the last glacial cycle:

690

form, flow, streams and lobes. Quaternary Science Reviews 25, 3359-3390.

691

692

Bradwell, T., Stoker, M., Larter, R. 2007. Geomorphological signature and flow dynamics of the

Minch palaeo-ice stream, NW Scotland. Journal of Quaternary Science 22, 609-617.

694 
698

699

Bradwell, T., Stoker, M.S., Krabbendam, M., 2008b. Megagrooves and streamlined bedrock in NW

701

702

Briner, J.P., Miller, G.H., Davis, P.T., Finkel, R.C., 2006. Cosmogenic radionuclides from fiord

landscapes support differential erosion by overriding ice sheets. Geological Society of America,

Bulletin 118, 406-420.

705

Briner, J.P., Miller, G.H., Finkel, R., Hess, D.P., 2008. Glacial erosion at the fjord onset zone and

implications for the organization of ice flow on Baffin Island, Arctic Canada. Geomorphology 97, 126134.

709

710

British Geological Survey (BGS), 1998. Cape Wrath. Scotland Sheet 113. Solid and Drift Geology,

711

1:50,000 Series. British Geological Survey, Keyworth, Nottingham, UK.

712

713

British Geological Survey (BGS), 2009. NC14, NC24. Superficial Deposits (Laxford Bridge, Loch Stack). 1:25,000 Series. British Geological Survey, Edinburgh, UK.

715

British Geological Survey (BGS), 2011. Bedrock Geology of the United Kingdom. DIGMAP50k. Digital

717 geological map and database. British Geological Survey, Keyworth, Nottingham, UK. 

Science Reviews 28, 677-692.

722

Clarke, G.K.C., 2005. Subglacial Processes. Annual Review of Earth and Planetary Sciences 33, 247276.

725

Clarke, G.K.C., Nitsan, U., Paterson, W.S.B., 1977. Strain heating and creep instability in glaciers and ice sheets. Reviews of Geophysics and Space Physics 15, 235-247.

728

Dahl, E. 1965. Plastically sculptured detail forms on rock surfaces in northern Nordland, Norway.

Geografiska Annaler 47A, 63-140.

De Angelis, H., Kleman, J. 2008. Palaeo-ice sheet onset zones: examples from the northeastern Laurentide Ice Sheet. Earth Surface Processes and Landforms 33, 560-572.

734

735 processes and rates. Geology 38, 423-426.

737 33.

Echelmeyer, K.A., Harrison, W.D., Larsen, C., Mitchell, J.E., 1994. The role of the margins in the dynamics of an active ice stream. Journal of Glaciology 40, 527-538. 
Evans, I.S., 1996. Abraded rock landforms (whalebacks) developed under ice streams in mountain areas. Annals of Glaciology 22, 9-16.

747

Eyles, N., 2012. Rock drumlins and megaflutes of the Niagara Escarpment, Ontario, Canada: a hardbed landform assemblage cut by the Saginaw-Huron Ice Stream. Quaternary Science Reviews 55, 34-

750 49.

751

Fabel, D., Stroeven, A.P., Harbor, K., Kleman, J., Elmore, D., Fink, D., 2002. Landscape preservation under Fennoscandian ice sheets determined from in situ produced 10Be and 26Al. Earth and

Planetary Science Letters 201, 397-406.

755

Fabel, D., Ballantyne, C.K., Xu, S., 2012. Trimlines, blockfields, mountain-top erratics and the vertical

dimensions of the last British-Irish Ice Sheet in NW Scotland. Quaternary Science Reviews 55, 91-102.

758

759

Geological Survey of Scotland, 1892. Lochinver. Sheet 107. Geological map, 1:63 360 scale. British

760

Geological Survey, Edinburgh, UK.

761

762

Glasser, N.F., 1995. Modelling the effects of topography on ice sheet erosion, Scotland. Geografiska Annaler 77A, 67-82.

764

Glasser, N.F., Bennett, M.R., 2004. Glacial erosional landforms; origins and significance for palaeoglaciology. Progress in Physical Geography 28, 43-75.

767

Gordon, J.E., 1979. Reconstructed Pleistocene ice sheet temperatures and glacial erosion in northern Scotland. Journal of Glaciology 22, 331-344. 
Gordon, J.E., 1981. Ice-scoured topography and its relationship to bedrock structure and ice movements in parts of northern Scotland and west Greenland. Geografiska Annaler 63A, 55-65.

Gordon, J.E., Sutherland, G.S., 1993. The Quaternary of Scotland. Geological Conservation Review Series, HMSO, London. 593pp.

Hall, A., Glasser, N.F., 2003. Reconstructing the basal thermal regime of an ice stream in a landscape of selective linear erosion: Glen Avon, Cairngorm Mountains, Scotland. Boreas 32, 191-208.

Harbor, J.M., 1995. Development of glacial-valley cross sections under conditions of spatially variable resistance to erosion. Geomorphology 14, 99-107.

Haynes, V.M., 1977. The modification of valley patterns by ice sheet activity. Geografiska Annaler 59A, 195-207.

Hindmarsh, R.C.A., 2001. Influence of channelling on heating in ice-sheet flows. Geophysical Research Letters 28, 3681-3684.

Hubbard, A., Bradwell, T., Golledge, N., Hall, A., Patton, H., Sugden, D., Cooper, R., Stoker, M., 2009. Dynamic cycles, ice streams and their impact on the extent, chronology and deglaciation of the last British-Irish Ice Sheet. Quaternary Science Reviews 28, 758-776.

Hughes, A.L.C., Clark, C.D., Jordan, C., 2010. Subglacial bedforms of the last British Ice Sheet. Journal of Maps 2010, 543-563.

Iverson, N.R., 1991. Potential effects of subglacial water-pressure fluctuations on quarrying. Journal 
Joughin, I., Tulaczyk, S., Bindschadler, R., Price, S.F., 2002. Changes in west Antarctic ice stream

800

velocities: observation and analysis. Journal of Geophysical Research 107 (B11), 2289,

801

doi:10.1029/2001JB001029.

802

803

Joughin, I., Smith, B.E., Howat, I.M., Scambos, T., Moon, T., 2010. Greenland flow variability from icesheet-wide velocity mapping. Journal of Glaciology 56, 415-430.

805

Kleman, J., 1994. Preservation of landforms under ice sheets and ice caps. Geomorphology 9, 19-32.

807

Kleman, J., Glasser, N., 2007. The subglacial thermal organisation (STO) of ice sheets. Quaternary

Science Reviews 26, 585-597.

810

Kleman, J., Hattestrand, C., Clarhall, A., 1999. Zooming in on frozen-bed patches: scale dependent controls on Fennoscandian ice sheet basal thermal zonation. Annals of Glaciology 28, 189-194.

813

814

Kor, P.S.G., Shaw, J., Sharpe, D.R., 1991. Erosion of bedrock by subglacial meltwater, Georgian Bay,

Ontario: a regional view. Canadian Journal of Earth Science 28, 623-642.

816

Krabbendam, M., Bradwell, T. 2010. The geology and landscape of the northwest Highlands: an

introduction. In: Lukas, S., and Bradwell, T. (Eds.), The Quaternary of Western Sutherland and Adjacent Areas: Field Guide. Quaternary Research Association, London, pp.3-12.

Krabbendam, M., Glasser, N.F., 2011. Glacial erosion and bedrock properties in NW Scotland: abrasion and plucking, hardness and joint spacing. Geomorphology 130: 374-383. 
824 Lawson, T.J., 1995. The Quaternary of Assynt and Coigach: Field Guide. Quaternary Research

825 Association, Cambridge, UK, 162pp.

826

827 Linton, D.L., 1963. The forms of glacial erosion. Transactions of the Institute of British Geographers $33,1-28$.

829

Lliboutry, L. 1968. General theory of subglacial cavitation and sliding of temperate glaciers. Journal of Glaciology 7, 21-58.

832

Lukas, S., Bradwell, T., 2010. Reconstruction of a Lateglacial (Younger Dryas) mountain icefield, in 580.

MacClintock, P., 1953. Crescentic crack, crescentic gouge, friction crack and glacier movement. Journal of Glaciology 61, 186.

839

840

McCarroll, D., Ballantyne, C.K., Nesje, A., Dahl, S.O., 1995. Nunataks of the last ice sheet in northwest

McIntyre, N.F., 1985. The dynamics of ice-sheet outlets. Journal of Glaciology 31, 99-107. 
850

851

852

853

854

855

856

857

858

859

860

861

862

863

864

865

866

867

868

869

870

871

872

873

Nye, J.F., 1957. The distribution of stress and velocity in glacier and ice sheets. Proceedings of the Royal Society of London, Series A 239, 113-133.

Paterson, W.S.B., 1994. The Physics of Glaciers. Third edition. Oxford, Pergamon.

Patterson, C.J., 1998. Laurentide glacial landscapes: the role of ice streams. Geology 26, 643-646.

Patton, H., Hubbard, A., Glasser, N., Bradwell, T., Golledge, N., 2012. The last Welsh Ice cap - Part 2:

Dynamics of a topographically controlled ice cap. Boreas, DOI:10.1111/j.1502-3885.2012.00301.x.

Payne, A.J., Dongelmans, P.W., 1997. Self-organisation in the thermomechanical flow of ice sheets. Journal of Geophysical Research 102, 12219-12234.

Peach, B.N., Horne, J., Gunn, W., Clough, C.T., Hinxman, L.W., Teall, J.H., 1907. The Geological Structure of the North-West Highlands of Scotland. Memoir of the Geological Survey of Great Britain, HMSO, Glasgow, UK.

Piotrowski, J.A., Larsen, N.K., Junge, F.W., 2004. Reflections on soft subglacial beds as a mosaic of deforming and stable spots. Quaternary Science Reviews 23, 993-1000.

Phillips, W.M., Hall, A.M., Mottram, R., Fifield, L.K., Sugden, D.E., 2006. Cosmogenic 10Be and 26Al exposure ages of tors and erratics, Cairngorm Mountains, Scotland: time scales for the development of a classic landscape of selective linear glacial erosion. Geomorphology 73, 222-245.

Rea, B.R., Evans, D.J.A., 1996. Landscapes of areal scouring in NW Scotland. Scottish Geographical Magazine 112, 47-50. 
Rea, B.R., Evans, D.J.A., Dixon, T.S., Whalley, B.W., 2000. Contemporaneous, localized, basal ice-flow 476.

878

881

Roberts, D.H., Long, A.J., 2005. Streamlined bedrock terrain and fast ice flow, Jakobshavns Isbrae,

West Greenland: implications for ice stream and ice sheet dynamics. Boreas 34, 25-42.

884

Ross, M., Lajeunesse, P., Kosar, K.A., 2011. The subglacial record of northern Hudson Bay: insights into the Hudson Strait Ice Stream catchment. Boreas 40, 73-91.

887

Schoof, C., 2005. The effect of cavitation on glacier sliding. Proceedings Royal Society London, Series A 461, 609-627.

890

891

Schoof, C., 2010. Ice-sheet acceleration driven by melt supply variability. Nature $468,803-806$.

892

893

Stoker, M.S., Bradwell, T. 2005. The Minch palaeo-ice stream, NW sector of the British-Irish ice sheet. Journal of the Geological Society, London 162, 425-428.

895 
901

902

903

904

905

906

907

908

909

910

911

912

913

914

915

916

917

918

919

920

921

922

Stokes, C.R., Spagnolo, M., Clark, C.D., 2011. The composition and internal structure of drumlins: complexity, commonality and implications for a unifying theory of their formation. Earth-Science Reviews 107, 398-422.

Stroeven, A.P., Fabel, D., Hättestrand, C., Harbor, J., 2002. A relict landscape in the centre of Fennoscandian glaciation: cosmogenic radionuclide evidence of tors preserved through multiple glacial cycles. Geomorphology 44, 145-154.

Sugden, D.E., 1968. The selectivity of glacial erosion in the Cairngorm Mountains, Scotland.

Transactions of the Institute of British Geographers 45, 79-92.

Sugden, D.E., 1974. Landscapes of glacial erosion in Greenland, and their relationship to ice, topographic, and bedrock conditions. Institute of British Geographers Special Publication 7, 177-195.

Sugden, D.E., 1977. Reconstruction of the morphology, dynamics and thermal characteristics of the Laurentide ice sheet at its maximum. Arctic and Alpine Research 9, 27-47.

Sugden, D.E., 1978. Glacial erosion by the Laurentide Ice Sheet. Journal of Glaciology 20, 367-391.

Sugden, D.E., Denton, G.H., 2004. Cenozoic landscape evolution of the Convoy range to Mackay Glacier area, Transantarctic Mountains: onshore to offshore synthesis. Geological Society of America Bulletin 116: 840-857.

Sugden, D.E., John, B.S., 1976. Glaciers and Landscape. Arnold, London. 
923

924

925

926

927

928

929

930

931

932

933

934

935

936

937

938

939

940

941

942

943

944

945

946

947

948

Sugden, D.E., Watts, S.H., 1977. Tors, felsenmeer, and glaciation in northern Cumberland Peninsula, Baffin Island. Canadian Journal of Earth Sciences 14, 2817-2823.

Sugden, D.E., Glasser, N., Clapperton, C.M., 1992. Evolution of large roches moutonnées. Geografiska Annaler, 74A, 253-264.

Trommelen, M.S., Ross, M., Campbell, J.E., 2012. Glacial terrain zone analysis of a fragmented paleoglaciologic record, southeast Keewatin sector of the Laurentide Ice Sheet. Quaternary Science Reviews 40, 1-20.

Truffer, M., Echelmeyer, K.A., 2003. Of isbrae and ice streams. Annals of Glaciology 36, 66-72.

Tulaczyk, S., Kamb, W.B., Engelhardt, H.F., 2000. Basal mechanics of Ice Stream B, west Antarctica. 1. Till mechanics. Journal of Geophysical Research 105, 463-481.

Weertman, J., 1957. On the sliding of glaciers. Journal of Glaciology 3, 33-38.

Whillans, I.M., Bentley, C.R., van der Veen, C.J., 2001. Ice streams B and C. AGU Antarctic Research Series $77,257-282$.

Winsborrow, M., Clark, C.D., Stokes, C.R., 2010. What controls the location of ice streams? EarthScience Reviews 103, 45-59. 
Fig. 1. Location of study area in NW Scotland (red box) and reconstructed British-Irish Ice Sheet

951 extent at Last Glacial Maximum (LGM). The LGM limit (c. 25-27 ka BP) taken from Bradwell et al.

952 (2008b). Thick grey lines are generalised flow lines for major palaeo-ice streams (after Bradwell et 953 al., 2007, 2008b). MIS - Minch Ice Stream; offshore grey-shaded areas are trough-mouth fans; SSF Sula Sgeir Fan; BDF - Barra Donegal fan. Thin grey lines are bathymetric contours.

Fig. 2. Extent of study area, around Loch Laxford, NW Scotland. Simplified bedrock geology (BGS, 2011) overlain on hillshaded topographic base (NEXTMap DEM). Key placenames referred to also shown. Grid ticks [British National Grid] at 5-km intervals

Fig. 3. (A) Topography of the study area. Oblique view from the west looking toward the mountains of Arkle and Ben Stack. Generated in GeoVisionary ${ }^{\mathrm{TM}}$; note $2 \mathrm{x}$ vertical exaggeration, scene lit from NW. [NEXTMap DEM with colour aerial photographs draped over.] Lines show topographic profiles used to derive roughness values in ArcGIS (lower panels). (B) Photograph looking NE across Loch Laxford, taken from near Cnoc Gorm, showing typical cnoc-and-lochan Lewisian gneiss terrain.

Fig. 4. Physiography of the study area. Hillshaded NEXTMap Britain digital elevation model highlighting the different terrains (upper panel). Landscapes of glacial erosion (after Haynes, 1977) are shown (red line and font); landscape types (modified from Krabbendam and Bradwell, 2010) also shown (white line and font). Note Haynes's line taken from small-scale map, hence boundary is 
data (lower panels). (left) Hillshaded NEXTMap DSM; (middle) NEXTMap radar reflectance data; (right) colour, orthorectified, digital aerial photograph.

Fig. 5. Classification scheme for glacio-erosional bedform zones on crystalline (shield) rocks in NW Scotland. Arrow in each image denotes former ice-flow direction.

Fig. 6. Examples of glacio-erosional bedrock bedforms, typical of zones 1-4, in Loch Laxford area, NW Scotland. All bedforms are on Lewisian gneiss bedrock. (A) Wholly abraded whaleback outcrops with well-developed p-forms on Creag na Fionndalach; glacially abraded islands in Loch Laxford in background (zone 4) [British National Grid: 219773, 948726]. (B) Linear undercut s-form channels (s) and smooth mamillated surfaces ( $p$-forms, $p$ ) on Cnoc Gorm; boundary between zones 4-3. Pencil indicates former ice flow direction (away from viewer) [BNG: 216690, 949804]. (C) Gently concave pforms on wholly abraded outcrops near Cnoc Grosvenor (zone 4). Notebook for scale [BNG: 228042, 943684]. (D) Subtle, weathered p-forms and undulating abraded surfaces (p) (zone 3); Handa Island (h) in background showing little bedrock exposure [BNG: 216563, 948466]. (E) Typical zone 2 terrain, near Gorm Loch. Stoss-lee forms are common but p-forms are rare; glacially transported boulder is ca. $1 \mathrm{~m}$ in diameter. Ben Stack in centre background. Palaeo-ice flow towards viewer [BNG: 220130, 944530]. (F) Typical zone 1 terrain, at $540 \mathrm{~m}$ asl on Ben Stack, with weakly abraded stoss surfaces (st), and some evidence of lee-side plucking (Is). Palaeo-ice flow from left to right. Rucksack for scale [BNG: 227627, 941667].

Fig. 7. Extract of $6-\mathrm{km}^{2}$ summary geomorphological map centred on Ben Stack. Note the simple geomorphological mapping scheme. Numbers in cells (bottom right corner) denote cell value 
according to zone classification (see Fig. 5). Some generalisation of field data and survey transects made to allow map reproduction at appropriate scale.

Fig. 8. (A) Compilation map of raw data from field surveys. [Base map = NEXTMap Britain hillshaded DEM.] Some generalisation made to allow reproduction at appropriate scale, overlapping data points have been removed for clarity. Rose diagram of glacial striae measurements (upper left). (B) Final grid of mapped cells, attributed according to zone classification scheme (see Fig. 5) and colour coded to highlight spatial trends. (C) Final colour-coded grid of cells (semi-transparent) with glacioerosional bedform zones defined (solid lines $=$ high confidence boundaries; dashed lines = lower confidence or inferred boundaries). Grid ticks on all maps at 5-km intervals.

Fig. 9. Small extract of summary map centred around Foindle, on south shore of Loch Laxford. This $1-\mathrm{km}^{2}$ site was used to test the mapping methodology, with repeat surveys of the same four grid cells employed. Bold numbers in cells (bottom right corner) denote initial zone classification value; numbers in brackets denote repeat zone classification value.

Fig. 10. Preservation of glacial surface features. (A) Wholly abraded Lewisian gneiss outcrop near Badcall Bay. Note the typical degree of surface weathering $(\sim 10 \mathrm{~mm})$ that has removed all glacial abrasion marks. $p=p$-forms. Rucksack for scale. (B) Weakly preserved glacial striae and polish on abraded Lewisian gneiss outcrop in Loch na Mnatha. In this instance, the surface features have been protected from weathering by submergence below water; $f=$ foliation in gneiss. Pencil for scale. (C) Well preserved glacial striae and friction cracks (fc) on quartzite bedrock. These unusually orientated striae (240/060) are from ice being deflected through the col between Arkle and Foinaven. (D) Marked contrast between weathered bedrock slabs without striae and unweathered bedrock with 
well-preserved glacial striae. The unweathered surface was revealed by removal of soil and glacial debris. Note the unidirectional striae with orientations 310/130; Torridon sandstone, Handa. Arrows in images denote former direction of ice flow.

Fig. 11. (A) Glacio-erosional zone map superimposed on topographic (onshore only) digital surface model (NEXTMap Britain DEM). (B) Glacio-erosional zone map superimposed on bedrock geology base (BGS, 2011). See Fig. 2 for geological key and placenames. Grid ticks at 5-km intervals.

Fig. 12. Interpretation of palaeo-ice sheet dynamics associated with the Laxfjord ice stream tributary, NW Scotland. Glacio-erosional zone map superimposed on digital surface model (with compressed colour ramp showing elevation). Arrows show general ice-sheet (basal) flow direction; arrow size indicates relative ice velocity. Colour scheme is also a proxy for ice sheet basal temperature; coldest colours show areas of frozen bed; warmest colours show highest inferred basal temperatures. (Elevation data: NEXTMap Britain DEM.)

Fig. 13. (A) Temperature profile (in ${ }^{\circ} \mathrm{C}$ ) of Jakobshavn Isbrae, west Greenland, at right angles to flow. Redrawn from Truffer and Echelmeyer (2003). Temperatures are relative to the local pressure melting point and thus appear as $0^{\circ} \mathrm{C}$ for the warmest layer. Height axis (in metres) normalised to zero at bed. (B) Cross-profile of Loch Stack trough (at right angles to palaeo-ice flow) showing inferred thermal (and rheological) zonation within palaeo-ice-stream tributary; glacio-erosional zones also shown (0-4). Same horizontal scale as (A) but $2 x$ vertical scale (values in metres). Note absolute ice-sheet thickness in NW Scotland is poorly defined; value has been taken from previous modelling experiments with ice streaming invoked (Boulton and Hagdorn, 2006 (1250 m); Hubbard et al., $2009(1000 \mathrm{~m}))$. 
Glaciological interpretation of glacio-erosional zones

\begin{tabular}{|c|c|c|c|c|c|}
\hline Zone & $\begin{array}{l}\text { Thermal } \\
\text { regime }\end{array}$ & $\begin{array}{l}\text { Ice rheology } \\
\text { near bed }\end{array}$ & Basal cavities & Basal meltwater & $\begin{array}{l}\text { Inferred relative ice velocity } \\
\text { [flow dynamics] }\end{array}$ \\
\hline$\overline{4}$ & $\begin{array}{l}\text { warm } \\
\text { [strain heating] }\end{array}$ & softest & rare / absent & rare? & accelerating [tributary onset] \\
\hline $3-4$ & warm & soft & absent $->$ common & present & fast $^{\mathrm{a}}$ [tributary flow] \\
\hline 3 & warm & soft / transitional & common & present & moderate to fast [shear/strain margin?] \\
\hline 2 & warm & hard / transitional & common & present & moderate \\
\hline 1 & $\begin{array}{l}\text { cold to warm } \\
\text { [transitional] }\end{array}$ & hard & rare / common & rare & slow [low shear stress?] \\
\hline 0 & cold based & hardest & absent & absent & nil [frozen to bed] \\
\hline
\end{tabular}

${ }^{a}$ Note: zone 3-4 velocities probably increased downstream. 


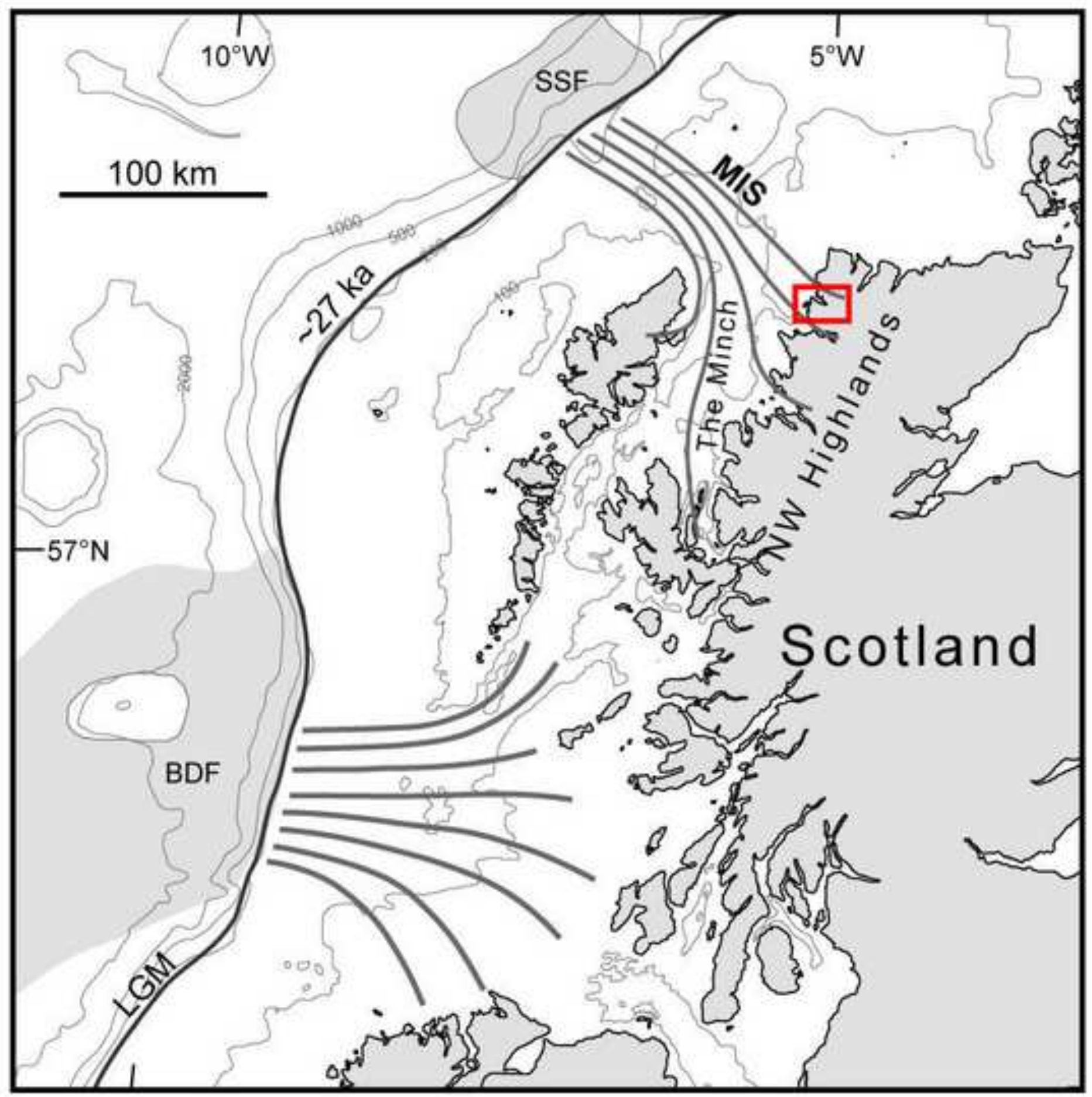


Click here to download high resolution image

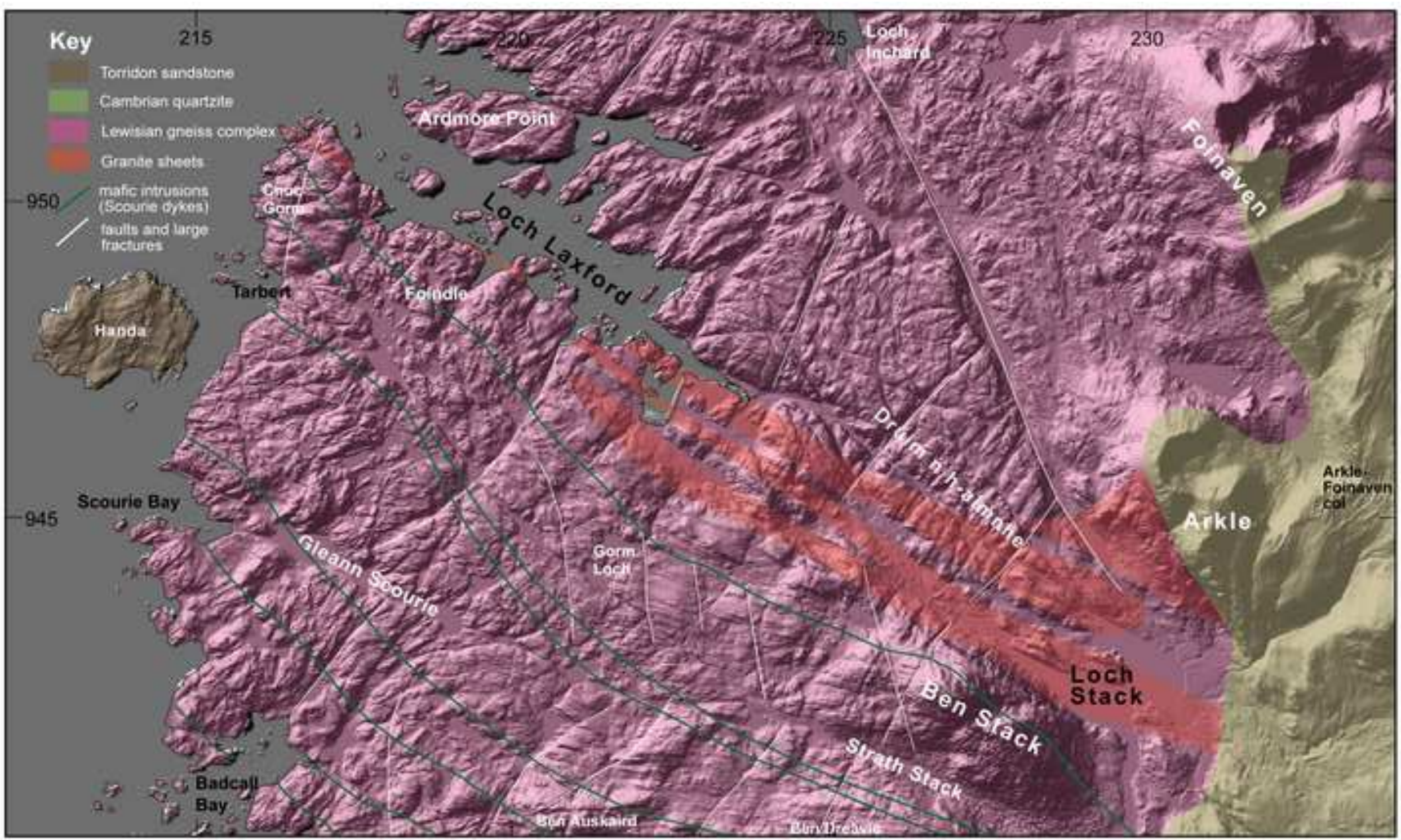


Click here to download high resolution image

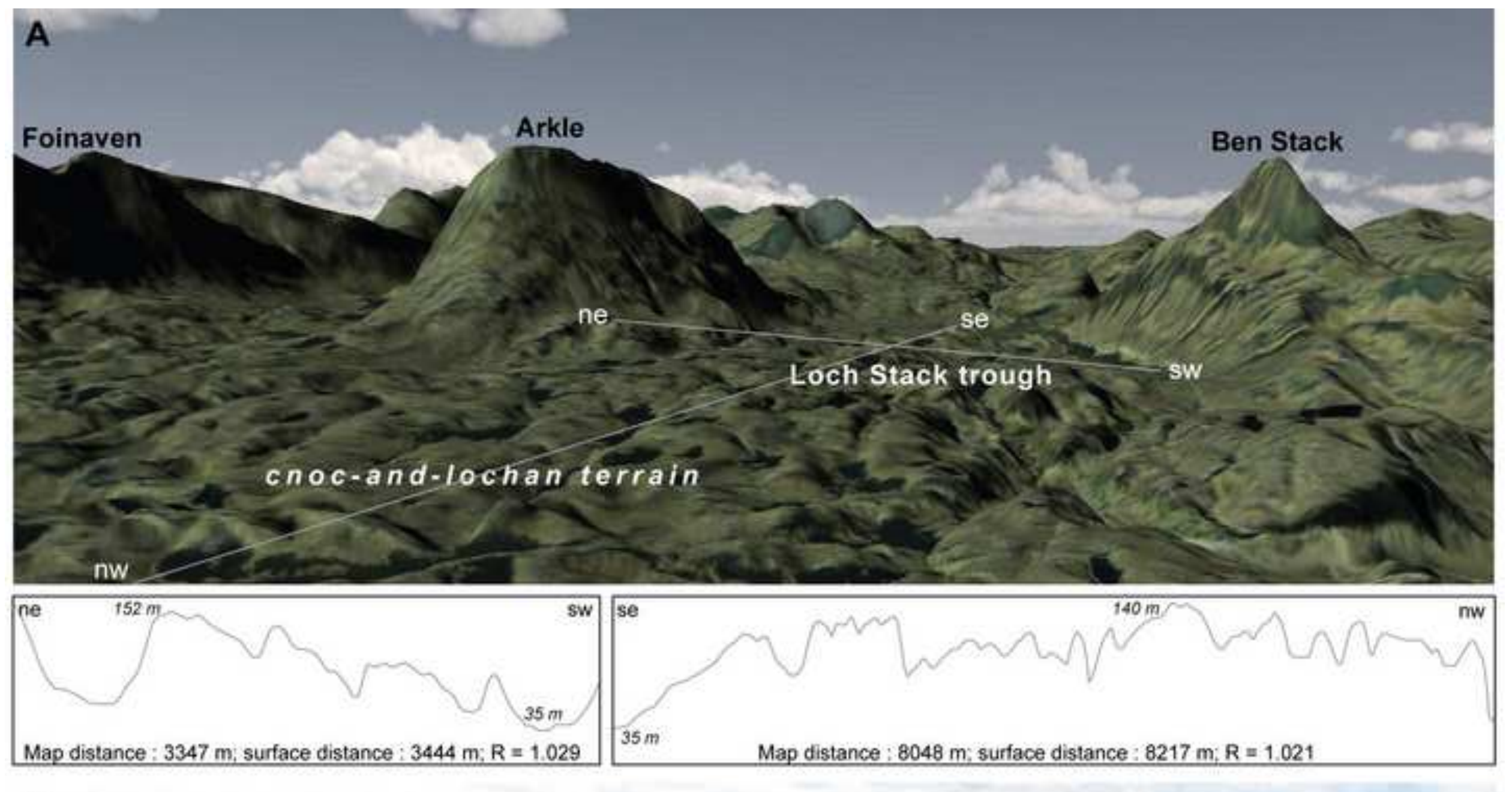

B
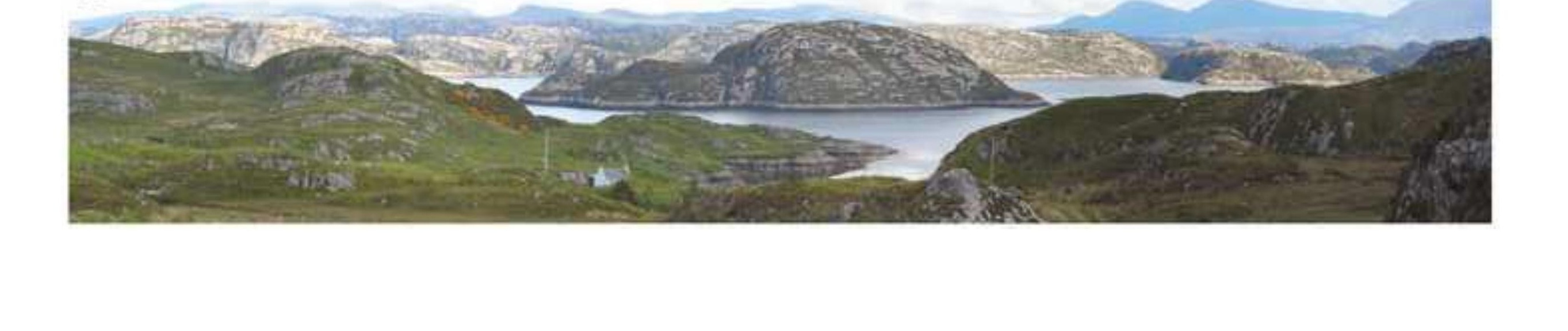

B 
Click here to download high resolution image
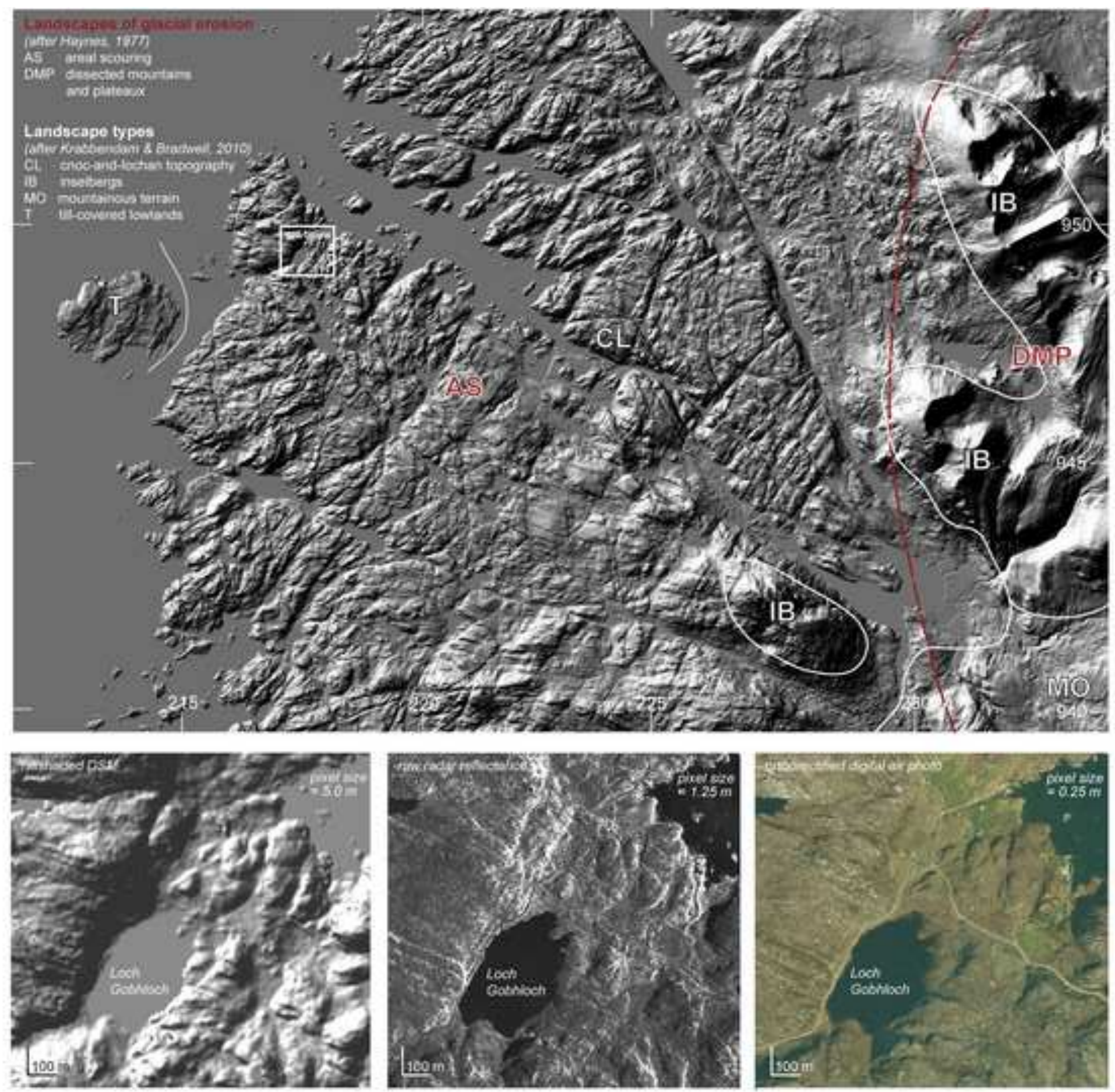

cins

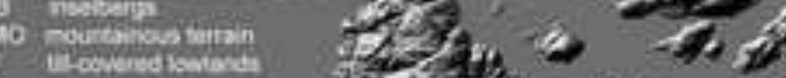

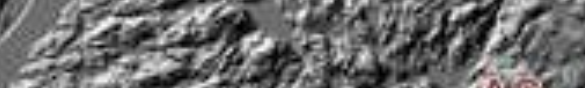

Tet 290

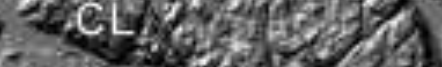




\section{Click here to download high resolution image}

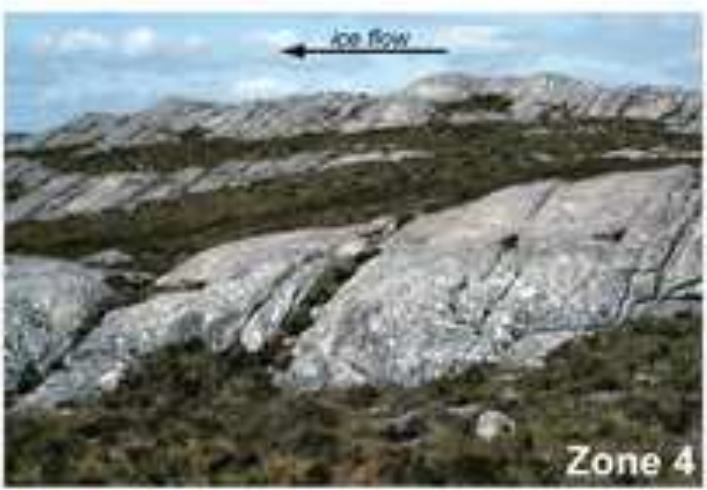

description

wholly abraded forms predominate

stoss-lee forms rare (or absent)

p-forms common

striae present

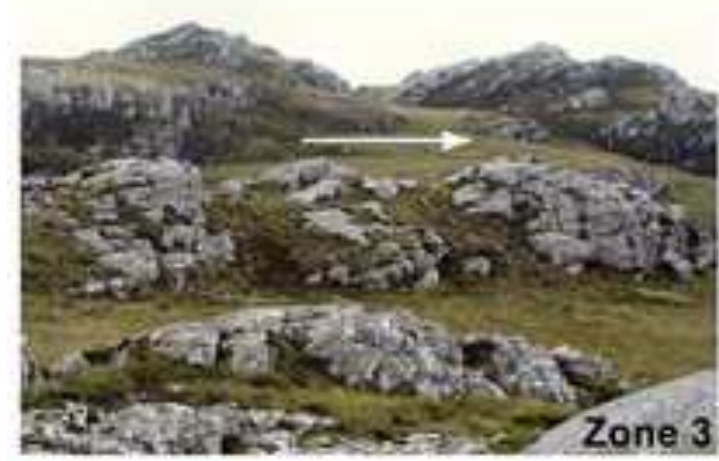

description

stoss-lee forms common

wholly abraded forms common

p.forms present

striae present

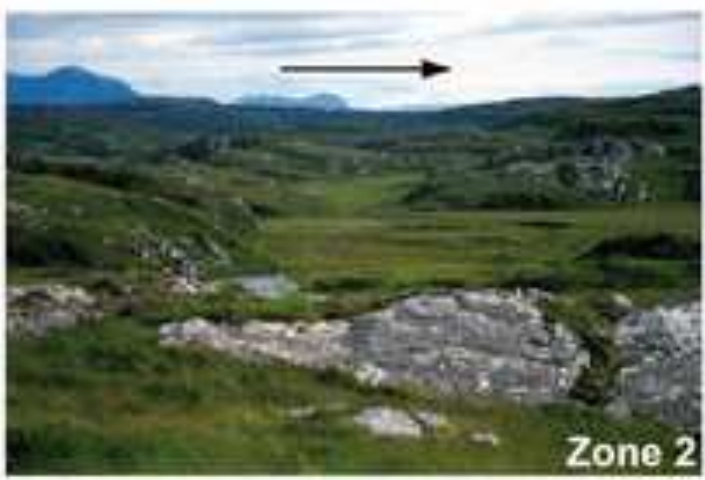

description

stoss-lee forms predominate

wholly abraded forms rare (or absent)

p-forms rare (or absent)

striae present

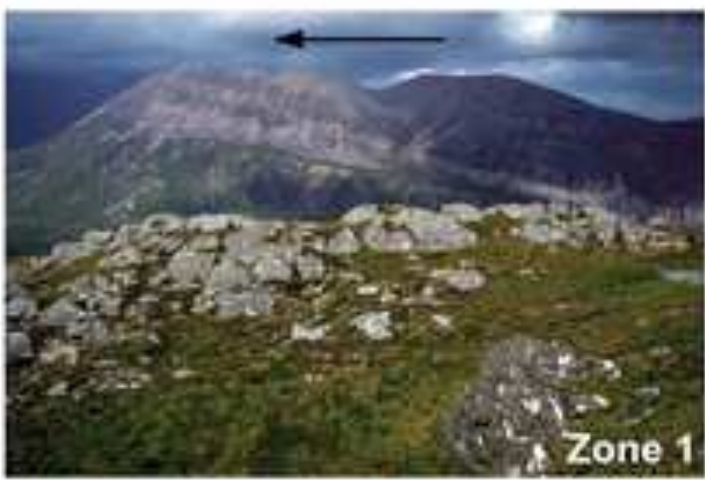

description

plucked faces common

subtle stoss-lee focms present

striae present

wholly abraded forms absent

p-forms absent

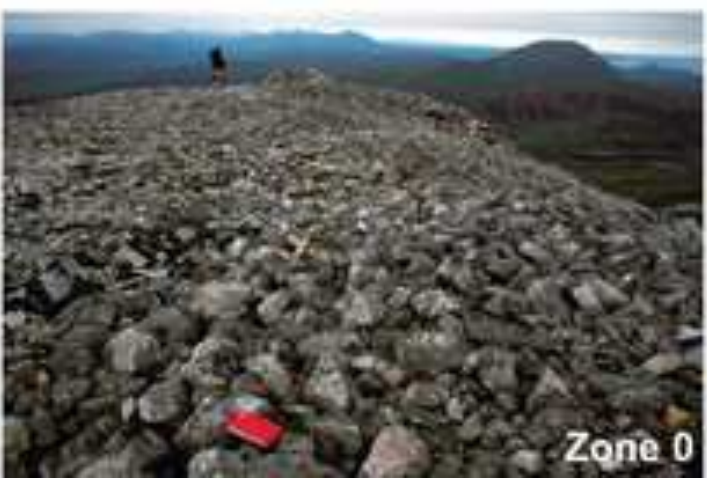

description

erosional forms absent

preglacial / periglacial debris common 
Figure 6
Click here to download high resolution image
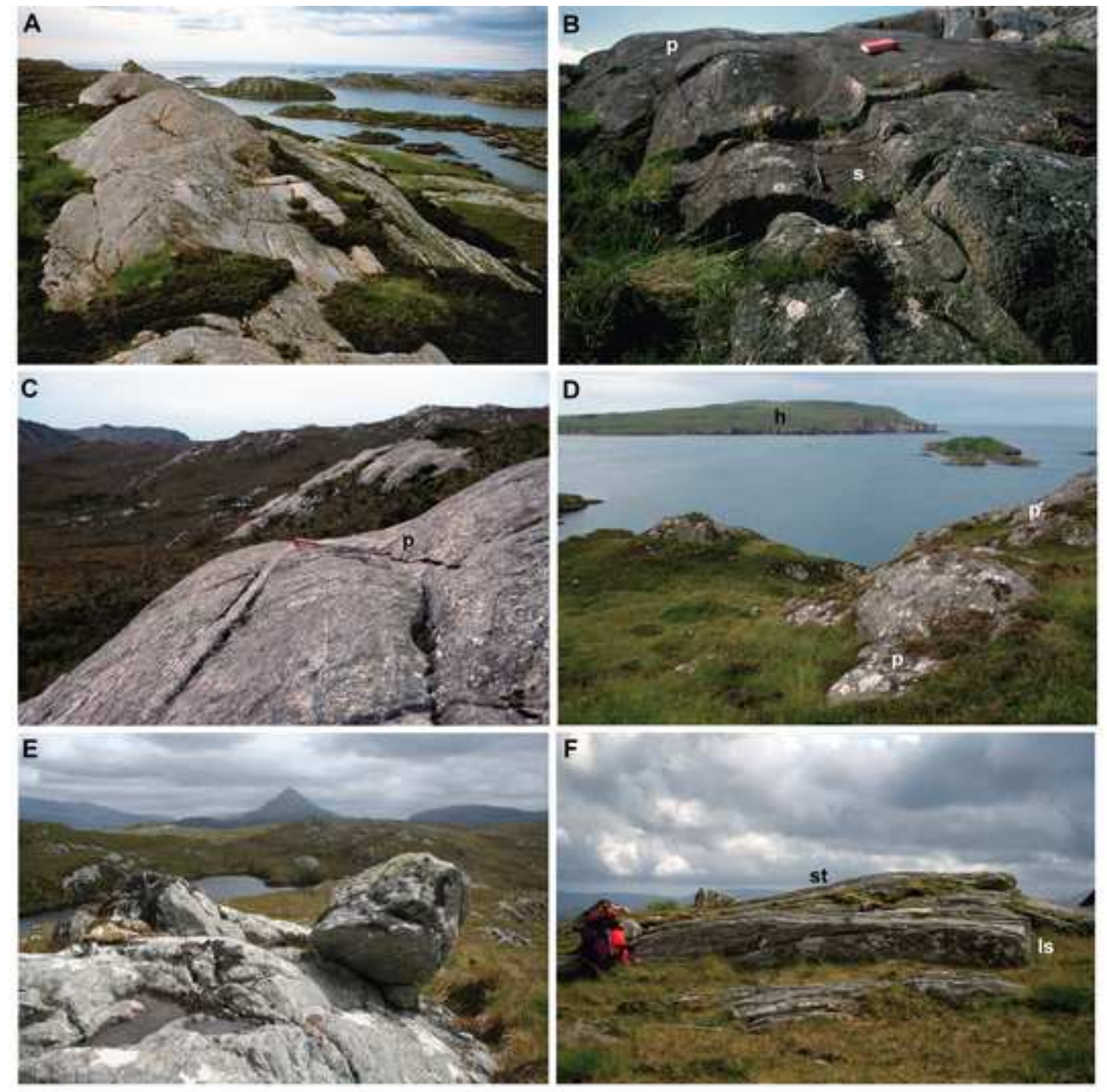

Fiqure6 
Click here to download high resolution image

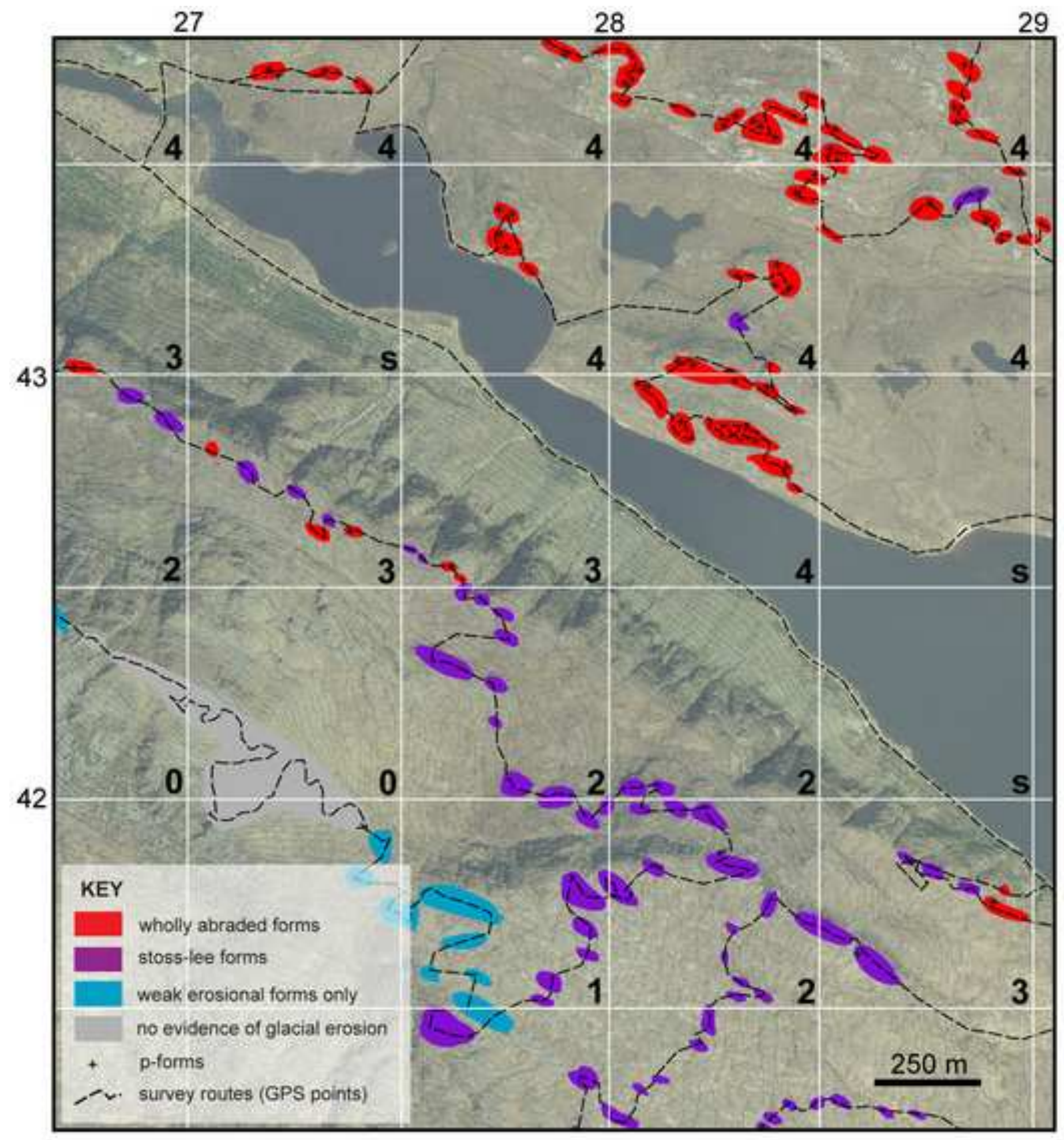


Click here to download high resolution image

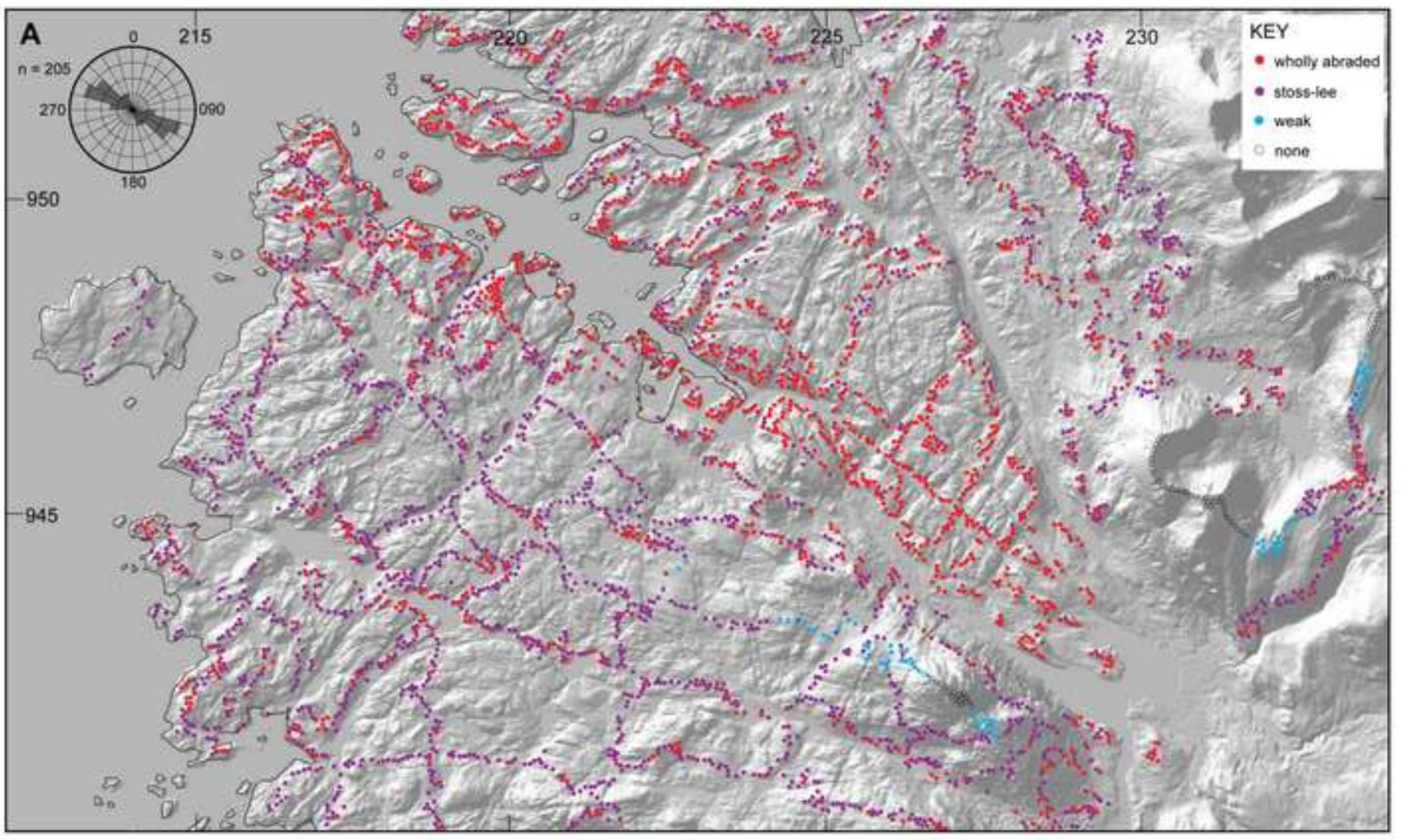




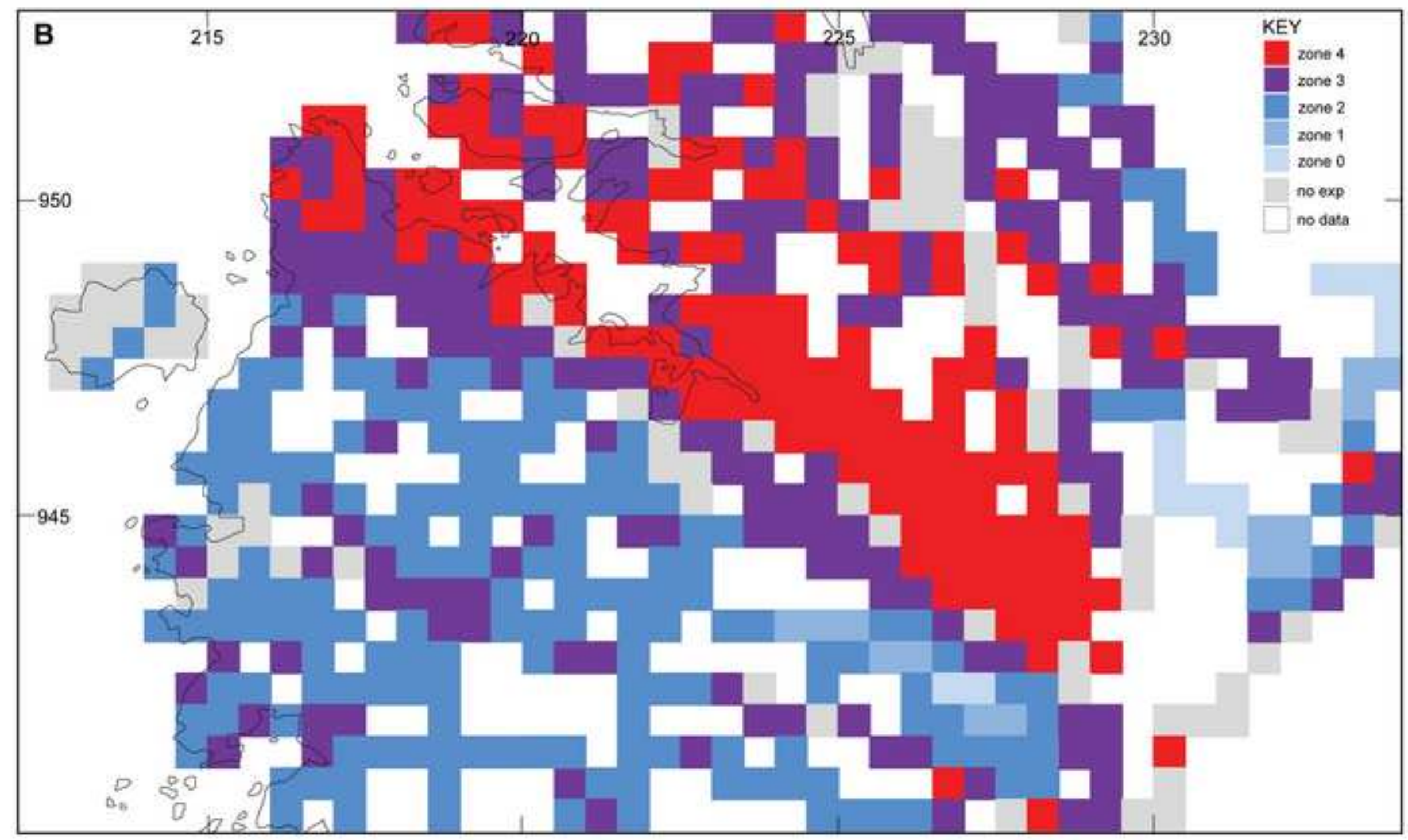




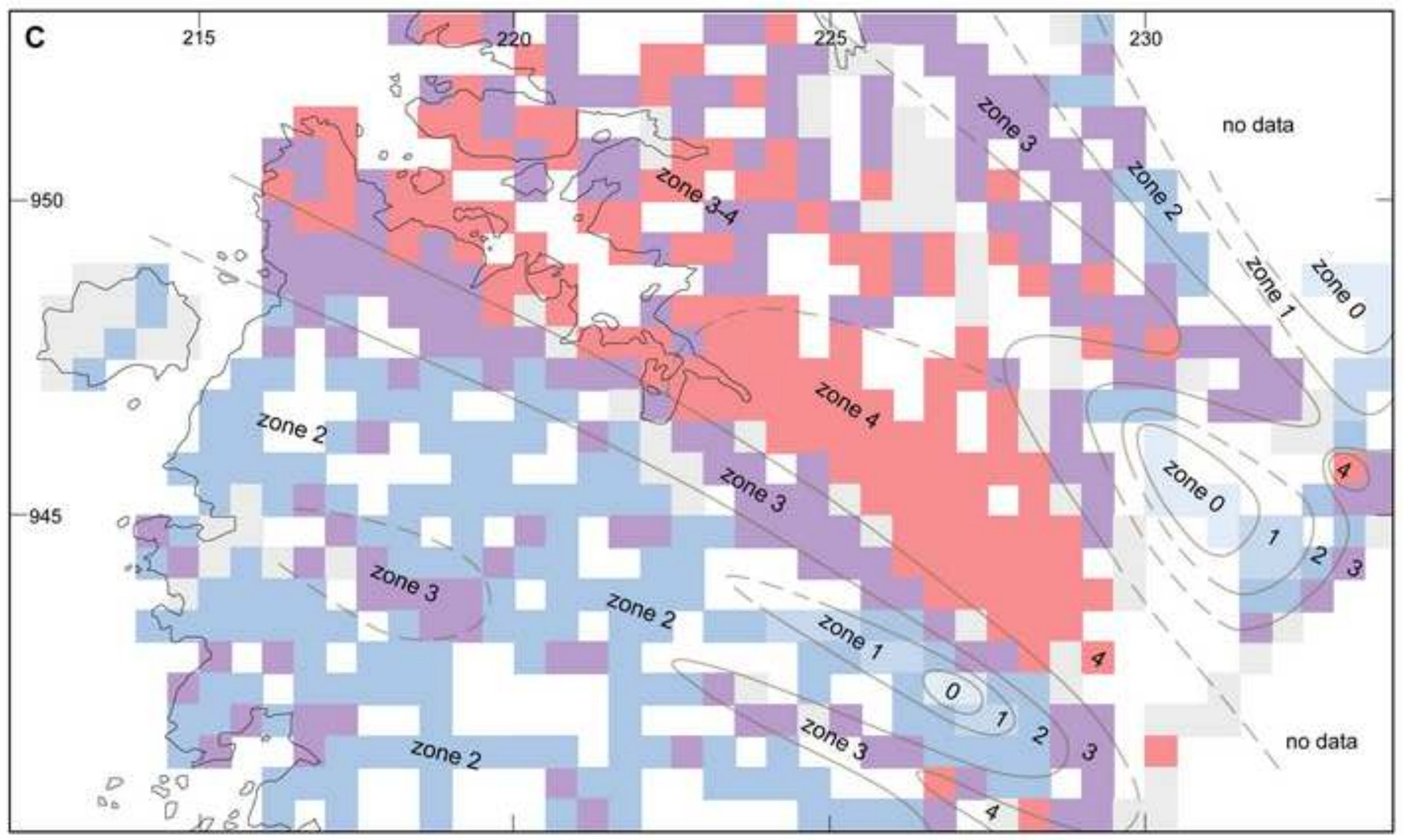




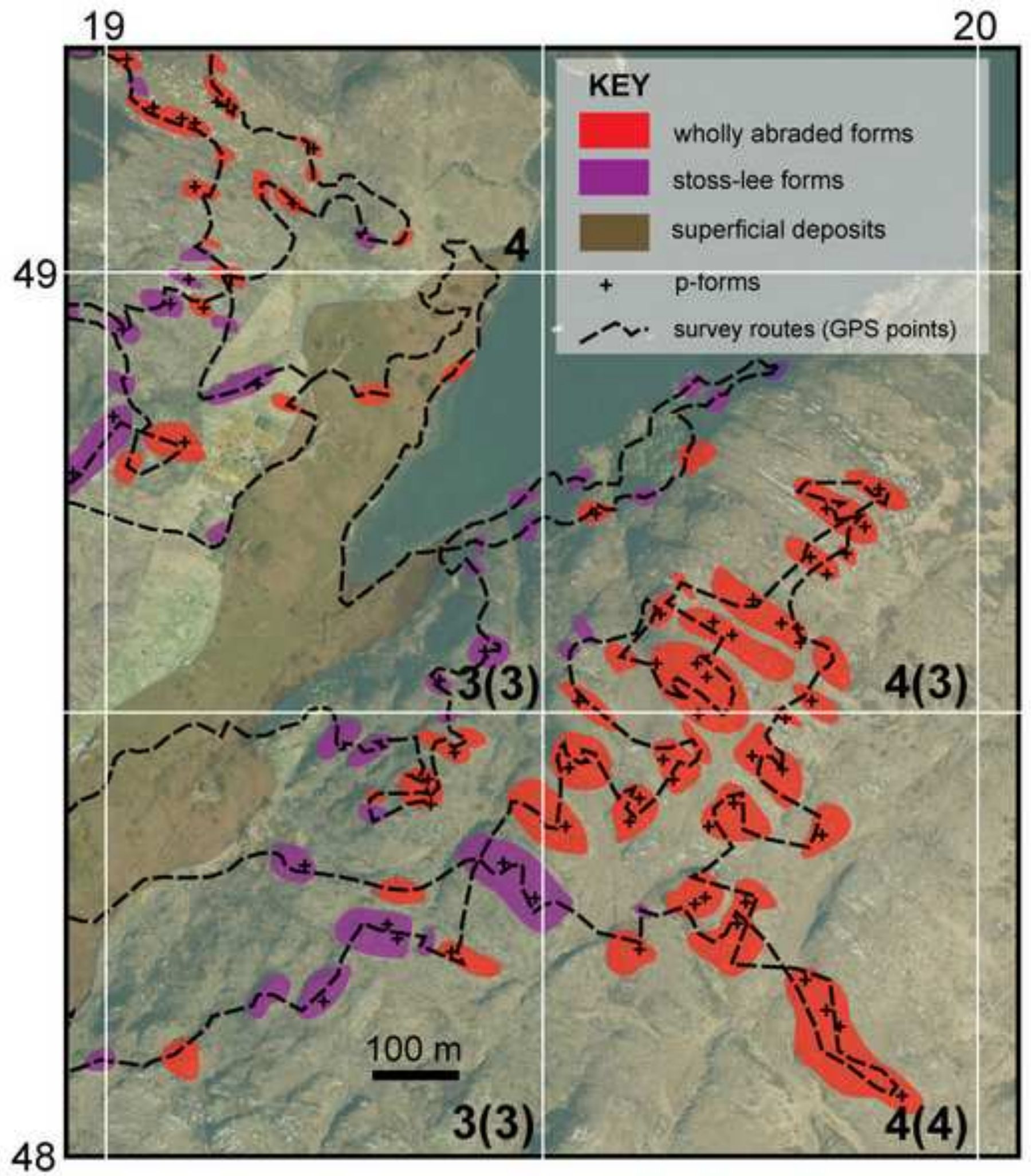



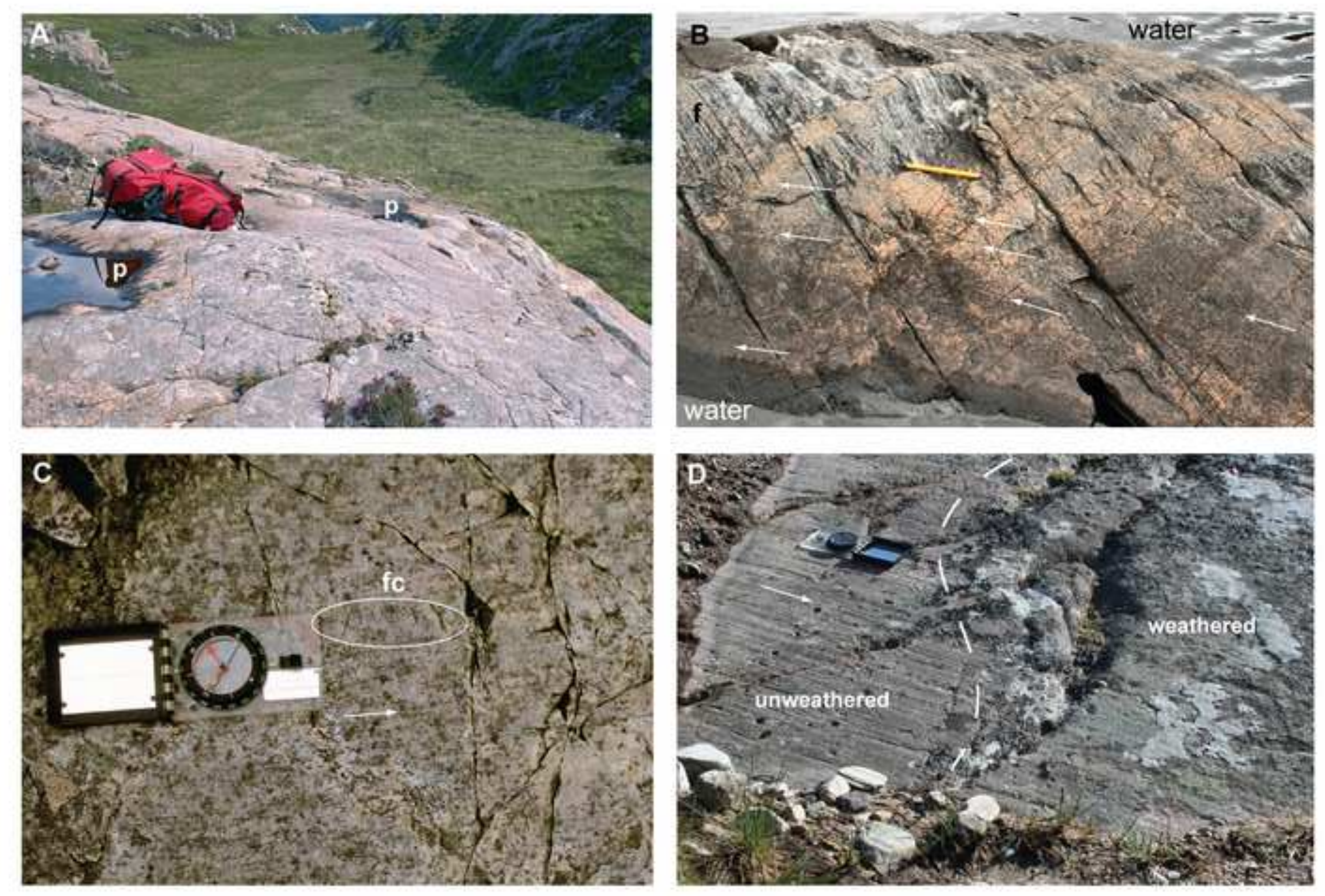


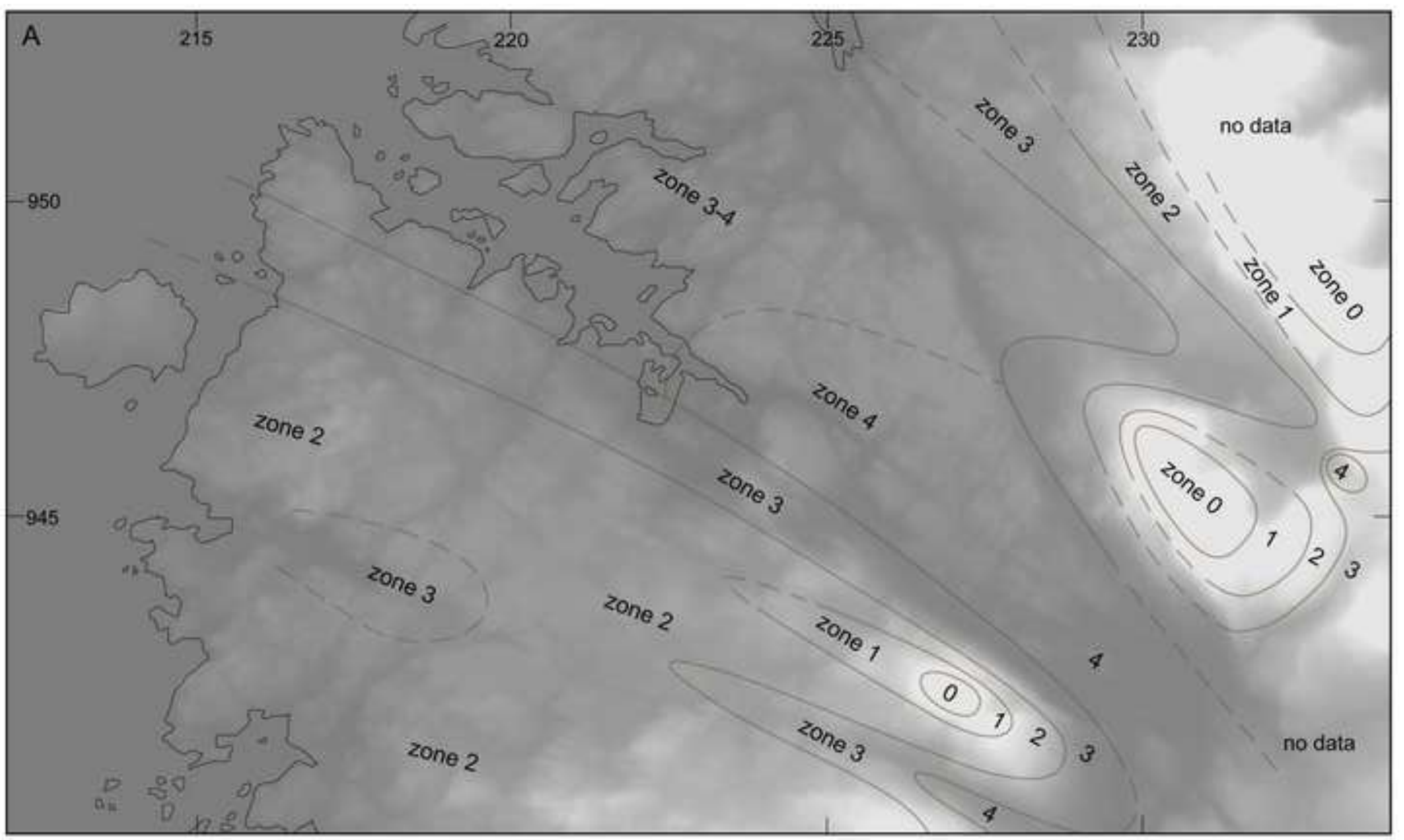




\section{Figure11B}

Click here to download high resolution image

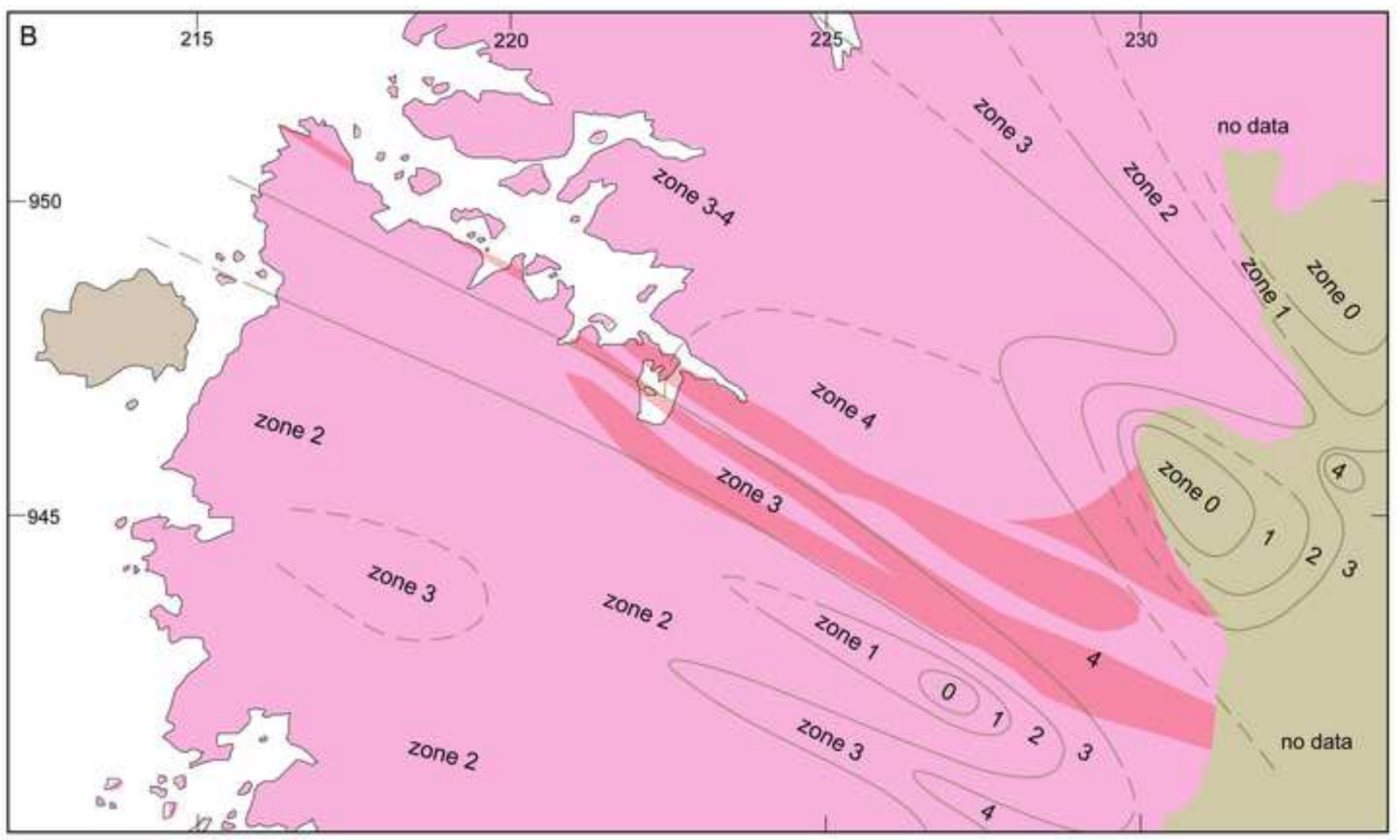




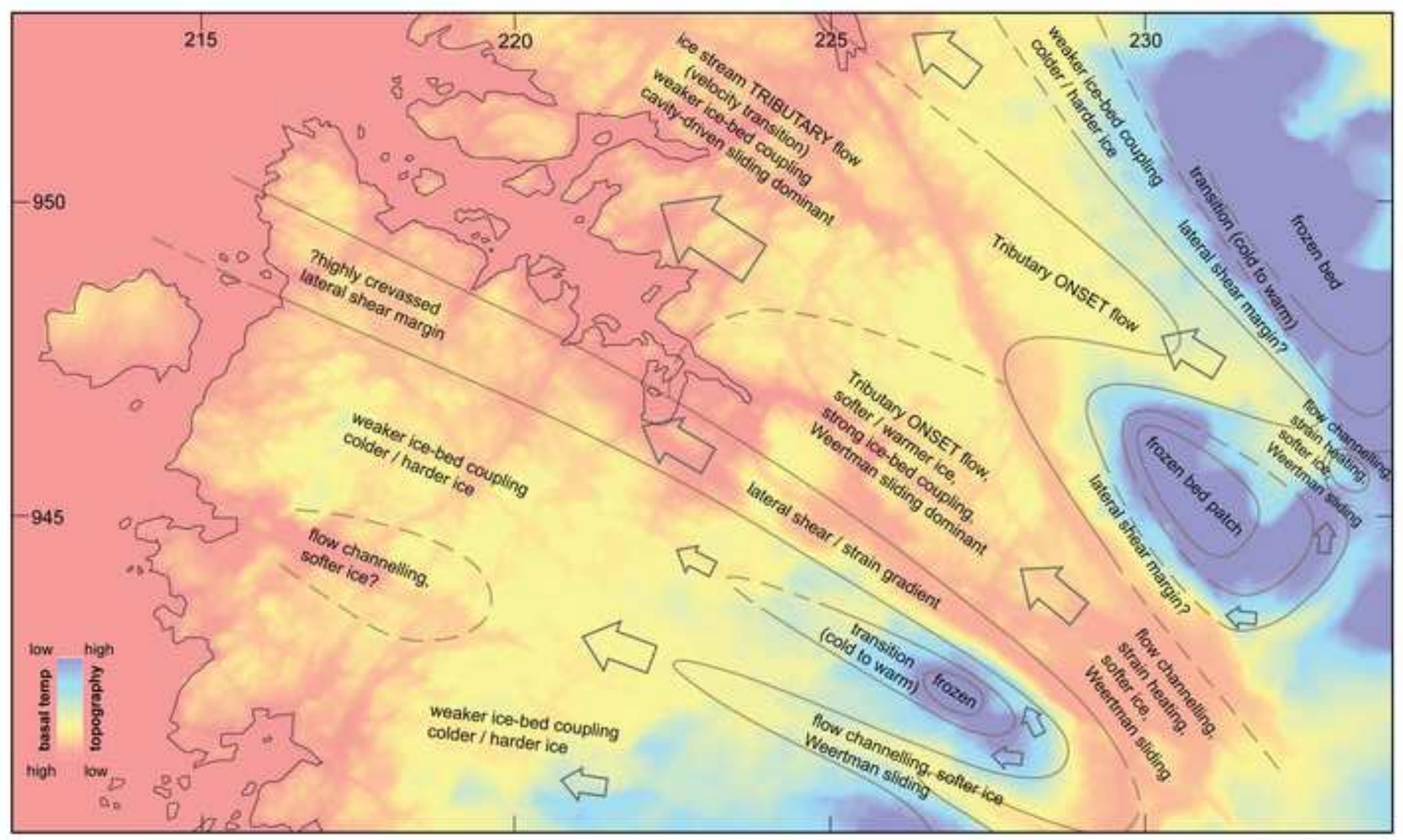


Click here to download high resolution image

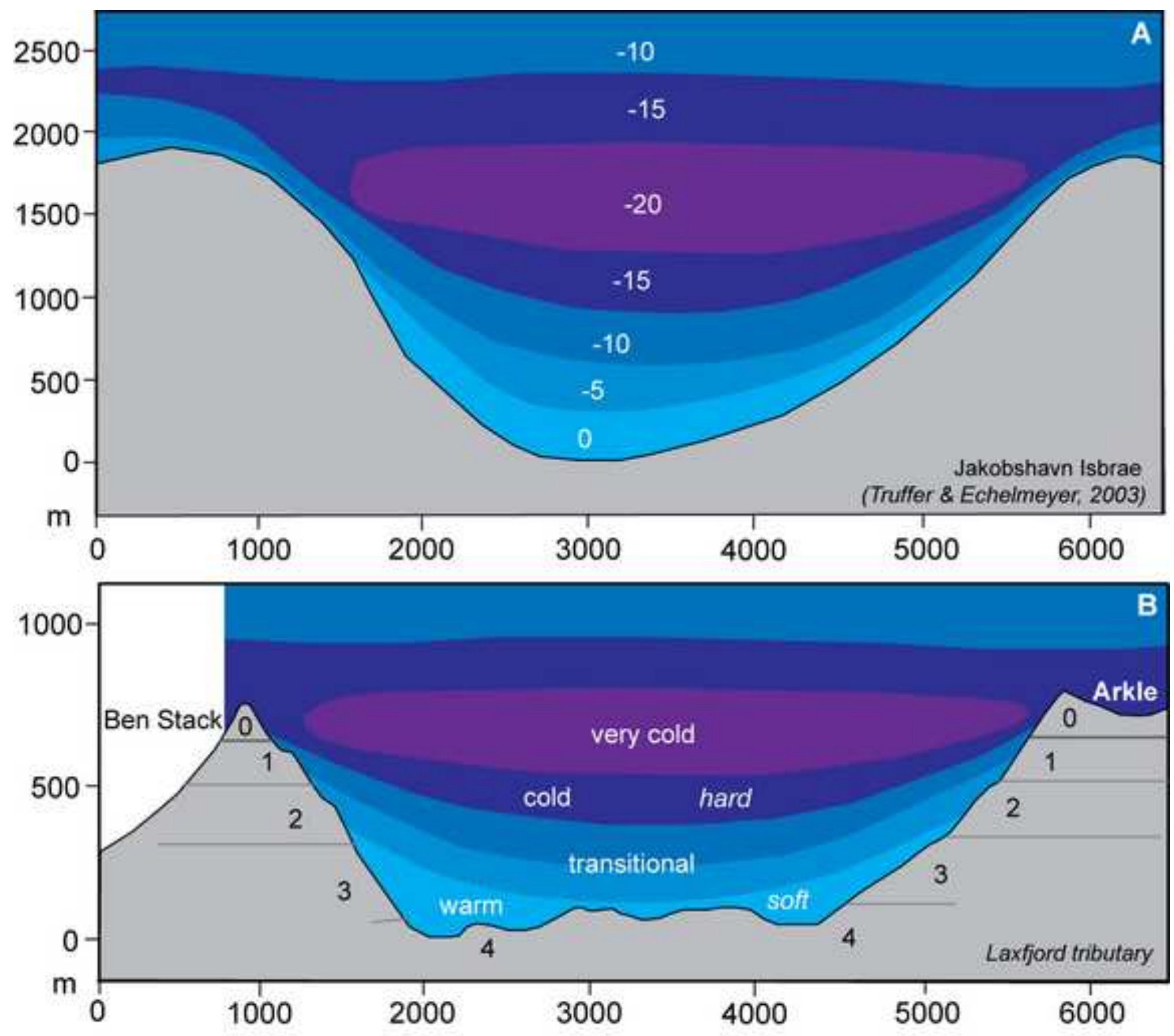

